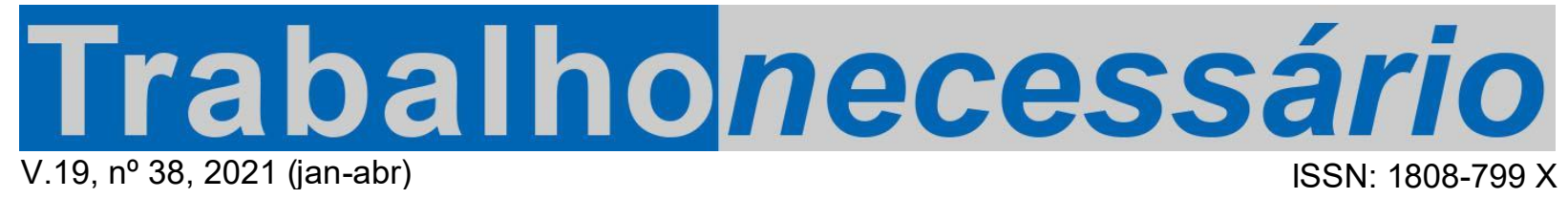

\title{
DIÁLOGOS COM LÚCIA XAVIER: UMA TRAJETÓRIA DE LUTAS NO COMBATE AO RACISMO E À OPRESSÃO DAS MULHERES NEGRAS
}

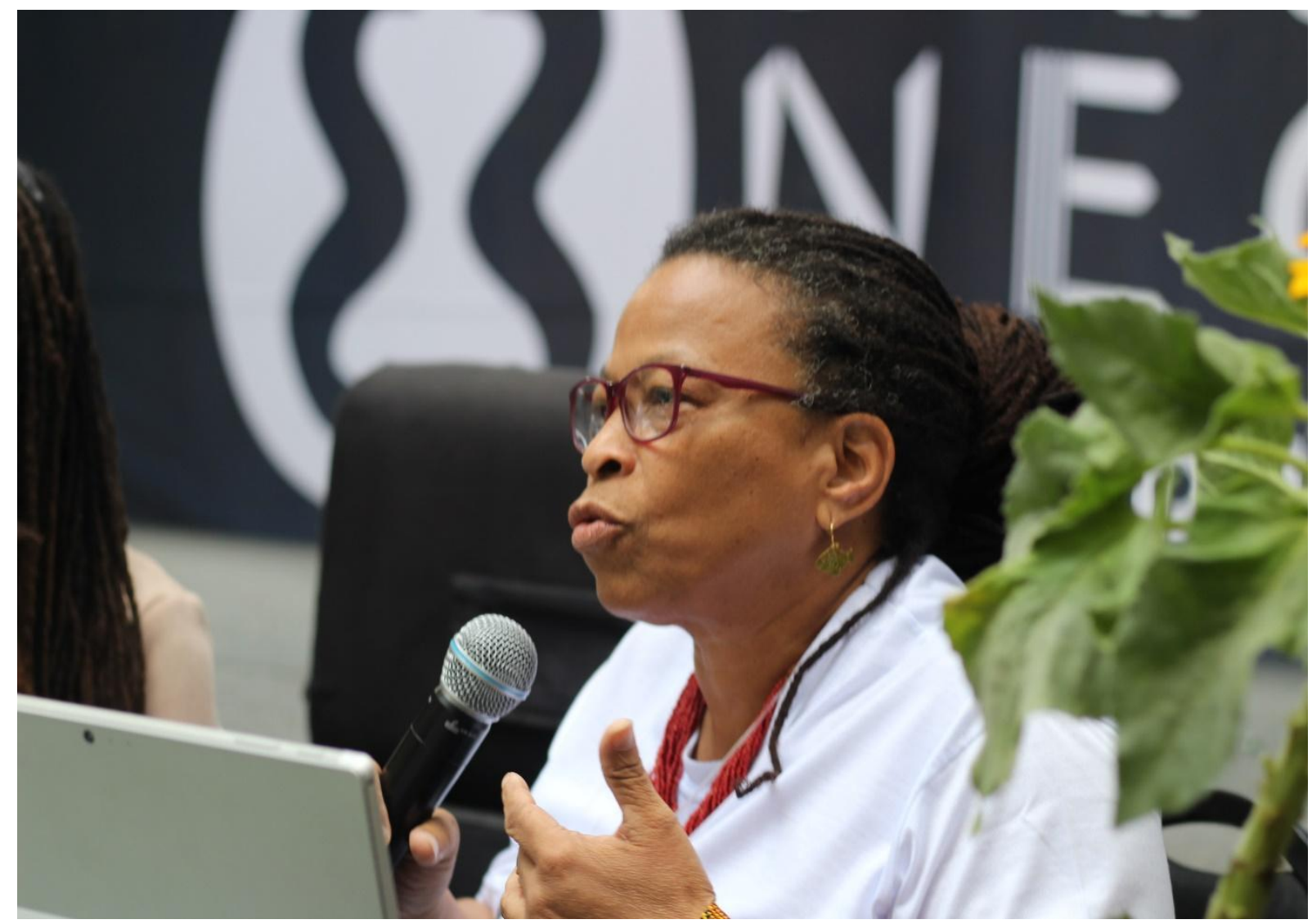

\section{Conversa ${ }^{1}$ entre Lúcia Xavier, Jacqueline Botelho ${ }^{2}$, Maria Cristina Paulo Rodrigues $^{3}$ e Tatiana Dahmer Pereira ${ }^{4}$}

\footnotetext{
${ }^{1}$ Recebido em 11/02/2021. Aprovado pelos editores em 12/02/2021. Publicado em 25/02/2021. DOI: https://doi.org/10.22409/tn.v19i38.48725

2 Professora Adjunta da Escola de Serviço Social da UFF. Doutora em Serviço Social (PPGSS/UERJ). Coordenação do NEPEQ/ESS-UFF. E-mail: botelho.jacque@gmail.com; Lattes: http://lattes.cnpq.br/7423332568707388; ORCID: https://orcid.org/0000-0003-1989-5089

${ }^{3}$ Doutora em Políticas Públicas e Formação Humana (UERJ); Professora Adjunta da ESS/UFF; estudiosa da área do trabalho e dos movimentos sociais. E-mail: mcristina@id.uff.br; Lattes: http://lattes.cnpq.br/0279905252377710; ORCID: https://orcid.org/0000-0003-0545-2260

4 Doutora em Planejamento Urbano e Regional (IPPUR-UFRJ), docente e pesquisadora do PPGSSDR-UFF, formada em Serviço Social (UFRJ). Pesquisadora apoiada pelo CNPq. Email: tatianadahmerpereira@gmail.com Lattes: http://lattes.cnpq.br/2619212275317172 
No dia 17 de dezembro de 2020, em conversa com Jacqueline Botelho, Maria Cristina Rodrigues e Tatiana Dahmer, Lúcia Xavier, mulher negra, militante e reconhecida publicamente por seu engajamento nas lutas antirracistas, apresenta sua trajetória de lutas, explicitando a motivação de suas ações, conectadas com as relações sociais, que fundamentam suas experiências concretas como mulher negra e ativista. Desde muito cedo, em sua militância contra a opressão de mulheres negras, Lúcia Xavier implicou-se na defesa dos direitos humanos e na construção de espaços onde a história dessas mulheres pudesse ser ouvida e respeitada.

Nascida no subúrbio do Rio de Janeiro, em uma família com uma mãe doméstica e um pai radialista, que morre muito cedo, essa militante histórica do movimento negro, fundadora da ONG CRIOLA, nos sinaliza a preocupação com a urgência de respostas imediatas à realidade de opressão de negros e negras, que se manifesta cotidianamente. Lúcia Xavier foi formada em um contexto de ditadura empresarial-militar no Brasil, com fortes imposições e violências do trabalho, que lhe roubaram o tempo de vida e o convívio com familiares. Essa é uma tragédia atual, que acomete a maior parte da população negra, e tal elemento revela a objetividade esmagadora do racismo, quando não reduzido ao comportamento preconceituoso das pessoas.

Lúcia foi formada na contracorrente de um ambiente de resgate da cultura negra, presente nos bailes e clubes negros cariocas, que traziam o tema racial e a denúncia da discriminação para o debate, escondido pela elite brasileira, que definia - Brasil como um país de democracia racial. Antes mesmo da sua entrada na Universidade, inicia sua ação como militante organizada no enfrentamento ao racismo, o que qualifica sua formação, que não se encerra no espaço acadêmico, mas é enriquecida por uma ativa vida política.

Lúcia Xavier nos mostra uma trajetória voltada para o debate racial e de gênero, onde sempre esteve viva a preocupação com as demandas e necessidades de negros e negras, por muitas vezes manifestada em mobilizações de rua. A preocupação com ações concretas é muito marcante em sua trajetória, pois enxerga poucas possibilidades de sucesso em táticas antirracistas limitadas ao campo institucional. 
Lúcia Xavier é parte da memória viva do movimento negro organizado, e muito gentilmente nos concedeu essa entrevista valiosa, em forma de conversa, que nos ajuda a reviver as experiências do passado para reinventarmos o presente. Durante a conversa, para além de sua trajetória pessoal, Lúcia nos fala sobre as lacunas identificadas no campo organizacional, o que nos enriquece nas análises do passado, sem as quais não podemos olhar criticamente o presente.

A conversa, que reproduzimos abaixo, mostra-nos a luta histórica do povo negro contra a opressão, apesar do processo de apagamento e silenciamento promovidos pelo Estado brasileiro. Diante de uma conjuntura perversa e da atual perda progressiva de direitos sociais - com violência aberta contra as periferias das cidades e trabalhadores do campo - que cresceu exponencialmente com a chegada da extrema direita ao poder no Brasil, em 2018, e em diversos países do mundo, a Universidade revigora sua contribuição social com a produção do conhecimento crítico, e, pela mediação da teoria social, mostra-se comprometida com a transformação do real, evidenciando que homens e mulheres são sujeitos de sua própria história, ainda que não a faça sob as condições por eles definidas.

Com isto, apresentamos mais uma oportunidade de lembrar das marcas da falsa abolição, da necessidade de superação do mito da democracia racial, da violência que acomete crianças e adolescentes, mulheres e jovens negros nas periferias. A população negra vive sob a mira dos revólveres e "sob o olhar sanguinário do vigia", mas ainda há luta nas ruas, e sua verdade vem denunciar o racismo como arma ideológica de dominação, cuja atualidade voraz nos mostra que a questão racial não é tema secundário para aqueles(as) comprometidos(as) com um projeto de transformação social.

Jacqueline Botelho: Lúcia, seja muito bem-vinda. Para começarmos, então, a nossa conversa aqui hoje, gostaríamos que você nos contasse um pouco sobre a sua experiência pessoal, sobre sua história, considerando sua trajetória de luta no enfrentamento ao racismo. Seria muito bom a gente ouvi-la, Lúcia.

Lúcia Xavier: Obrigada Jacqueline, maior prazer em conversar com vocês, sobretudo com você. Acho que esse esforço de atuação política no campo do 
racismo, mesmo nas universidades, é um esforço que precisa ser sempre ressaltado.

Então, quem sou eu? Eu sou uma mulher negra, nascida de uma família de uma mãe doméstica, de um pai radialista que morre muito cedo, de uma família que todos os dois, tanto o pai como a mãe... meu pai tinha uma família extensa, já minha mãe não, minha foi doada para uma pessoa. Doada é uma maneira simples de dizer; alguém largou ela na mão de alguém. Mais tarde, eu conheço seus outros dois irmãos de outros casamentos, de sua mãe ou de seu pai, mas basicamente é com a família do meu pai que a gente vai conviver mais tempo, já que minha mãe, ao longo do tempo, vinha muito pouco em casa, dado o serviço doméstico.

Hoje, se o serviço doméstico oferece algumas mudanças, uma delas é o convívio familiar e comunitário, que era negado a essas mulheres que passavam praticamente muitos dias no trabalho, inclusive sábado e domingo. Por isso, a gente tem, eu particularmente, uma especial atenção ao trabalho doméstico, e acho que qualquer mulher negra desse país, quando começa a tratar dos problemas raciais, sobretudo da mulher negra, precisa olhar para esse lugar, né? Esse é um lugar muito complexo porque marca a nossa trajetória como mulheres negras, mas marca também a nossa trajetória de escolhas políticas e capacidades de enfrentamento às barreiras impostas pelo racismo.

Dito isso, minha mãe recebe uma oportunidade de nos juntar em uma casa com ela, eu já tinha doze anos - eu tenho sessenta e um, vou fazer sessenta e dois agora. E é nessa perspectiva que eu também vou mudar de região, de território. Tudo isso está entre Cordovil e Rocha Miranda, até que vim morar na Tijuca, bem perto do Centro da cidade, mas um outro mundo, né, o mundo da classe média, classe média carioca, que é muito, muito, muito importante de sinalizar, porque a Tijuca é o centro, né? Não é lá que estão todos os quartéis, mas tem bastante generais; não é lá que estava toda classe média rica, mas lá concentrava, de certa forma, o que pesava da classe média na política brasileira, inclusive no futebol. E, bom, ao vir morar na Tijuca, se abrem também outras possibilidades: não havia muita diferença de formação escolar, mas eu me lembro que a minha turma em Rocha Miranda, sei lá, tinha cinquenta alunos; quando eu chego na Tijuca minha turma é de final de ensino médio/de ensino fundamental tinha, sei lá, trinta alunos. Então, se tinha muito mais espaço, mais tempo, mesmo que as grades eram as mesmas, a formação não era a mesma. É nessa pegada que eu vou entrar toda a 
minha adolescência. Eu morava em uma casa de cômodo. Então, passei a morar em casa de cômodos até muito tempo depois (não, nem tanto tempo depois) da minha formatura. Mas até os vinte sete anos era assim que eu morava, em casas de cômodos coletivos, com banheiros coletivos, às vezes até com pias coletivas, às vezes até com cozinhas coletivas.

Essas mudanças ocorridas na minha vida, elas também vão marcar as experiências e processos de encontro com outras questões. Então, basicamente eu vivia mergulhada no mundo das domésticas, porque as adolescentes amigas eram todas domésticas, essa relação entre as meninas da classe média tijucana e as domésticas era intensa, umas estavam nas escolas e outras no mercado de trabalho. Mas vai ser quase no finalzinho da minha adolescência que eu vou me inteirar com a questão política. Isso não quer dizer que isso não era tratado na minha família. Minha família tinha regras muito objetivas sobre o racismo, desde pequeno a gente sabia do que se tratava, como se defender, como agir. Éramos uma família negra, então, uma família que tinha força nos lugares onde vivia, tinha voz de comando, tinha participação comunitária. Nesse caso, a nossa vivência em favela foi muito curta, pequena. A gente era muito pequena assim que meu pai morreu, mas como a gente vivia na casa dos nossos parentes, então esse era um outro mundo, um mundo mais organizado em termos familiar, de autoridade, de rotinas, e tudo mais.

Bom, com a minha mãe a gente vem viver um pouco também por nossa conta. Ela passava o dia inteiro trabalhando, trabalhava inclusive no sábado, então, essas coisas tinham outras perspectivas. Nesse sentido, vai ser já lá no segundo grau - e lógico né, toda a experiência política, debates políticos estão em família, que eu vou olhar um pouco mais as distinções da ditadura, as leituras sobre outras perspectivas, quer dizer, tudo aquilo que eu via ali, acompanhava trazido pela minha família, começa a aparecer concretamente nos jornais, na literatura, e tudo mais.

Há também um movimento muito forte na sociedade carioca, eu posso dizer da carioca, não sei dizer se ela tem extensão né, e por acaso, ouvindo Carlos Alberto Medeiros na defesa do seu doutorado, eu falei: "poxa, já não posso mais falar sobre isso que ele já concretizou em livro, em tese." Havia um movimento muito forte, cultural, no Rio de Janeiro, baseado na dimensão do enfrentamento ao racismo, da afirmação de uma identidade positiva negra, o Black is beautiful, baseado na Soul Music, e esse movimento arregimenta muitos jovens, e esses 
jovens vão se encontrando na praia, no samba, nos bailes de soul, nas atividades culturais que esse grupo vai vivenciando. Os bailes do Renascença, do Botafogo, da Portela, e também sambas, vão criando uma rede de encontros, e também, de possibilidades de mais debates sobre a questão racial. Você tinha um Agbara Dudu, você tinha o samba nas escolas de samba, você tinha os bailes soul e os outros bailes né, do período que você ia encontrando e também ia vendo o tipo de organização, a forma de pensar, o debate, a postura, a estética. E também, claro, isso estou analisando hoje; antes era só festa - festa que às vezes virava debate, mas festa, né. E também um encontro, um encontro de uma identidade, um debate sobre as coisas negativas que se via, as mortes violentas, a dificuldade na manutenção na escola, a procura de trabalho e que tipo de trabalho... então, é nesse ambiente que eu também vou me desenvolvendo em relação a isso.

Já um pouco antes, e mesmo depois de eu entrar na universidade, eu já faço parte de um grupo chamado "Acorda Crioulo", que tinha a sede Cidade de Deus, e lá eu também junto com a minha própria formação em Serviço Social - eu começo na UFF de Campos, eu passo para UFF no segundo semestre, mas passo UFF de Campos no primeiro semestre, não me lembro mais, e eu vou. Sabe que o Serviço Social nessa época era um trabalho de elite, lá estavam também as pessoas da classe média, classe média alta, e eu vou para o Serviço Social também um pouco desviada. Na verdade, eu me preparava para o Direito, para a formação em Direito, quando uma prima me disse: "ah, tem um negócio lá na minha faculdade" (ela fazia fonoaudiologia), que eu acho que você vai gostar, a sua cara”. E me mostrou aquele currículo complexo, o currículo falou um pouquinho de cada coisa, e acho que bateu na minha alma, porque eu sou uma pessoa muito dispersa. Eu começo pensando "ah vou fazer isso aqui", daqui a pouco eu estou olhando para outra coisa. E o currículo de Serviço Social era um pouco disso: tinha Ética, tinha Política, Antropologia, tinha psicologia, tinha filosofia, tinha estatística, tinha o "diabo a quatro" lá. E eu achei aquilo fantástico, muito interessante, e como esse grupo, o da minha prima também era um grupo espírita, e eu nessa época era espírita kardecista, ela falava muito de uma perspectiva do suporte da ajuda, mas, na verdade, o que eu gostei mesmo foi daquela mistura. Porque, vocês sabem, quando a gente é jovem a gente olha e fala: "ai, quero ser médica”. Daqui a pouco você diz: "quero ser psicóloga". Só quando a gente é criança que a gente define bem bombeiro, lixeiro, policial, mas na prática, quando a gente chega nessa fase, 0 
mundo, a gente acha que a gente conhece tudo que está lá, e por incrivel que pareça as nossas formações médias não explicam o mundo. Você não sabe bem o que faz o professor, não sabe o que faz o psicólogo, o médico. Você imagina que faz. Por quê? Porque é um mundo também cindido. Na minha família não tinha médico, não tinha psicólogo, não tinha engenheiro. Tinha era pedreiro, cozinheira, lavadeira, passadeira, costureira. E esse mundo oferecido de uma outra formação, você não conhece, só vai conhecer quando chegar na faculdade. Você não tem primo, não tem vizinho, não tem amigo que viva isso, né. Até me lembrei que eu tinha uma amiga que era empregada de uma mulher negra que era pneumologista, ou era, sei lá, nefro, não me lembro. Agora que me veio isso na mente, era uma família negra que morava na Tijuca, olha que legal! Me lembrei disso.

Aí, o que ocorre nessa fase? Eu escolho o Serviço Social, mas nessa fase eu encontro no movimento negro, na Cidade de Deus, um movimento complexo. E o que eu estou chamando de complexo? Eram negros discutindo a questão racial e agindo politicamente, então, era gente que quebrava o ônibus se o ônibus demorasse, era gente que fazia manifestação na porta do serviço de saúde, era gente que fazia reunião na praça perguntando por que na praça não tinha parque, não tinha isso, não tinha aquilo. Então, na verdade, era exatamente como eu pensava a questão racial, e ao mesmo tempo, era diferente do que se fazia com a questão racial. Por quê? Porque mesmo depois da minha segunda organização que foi o IPCN [Instituto de Pesquisa das Culturas Negras], essas questões eram pensadas desde o ponto de vista da transformação, da revolução, então, elas eram pensadas olhando para isso: "esse modelo não serve, vamos mudar, tem que construir outra coisa”. E, nesse sentido, as dinâmicas de interação com os problemas sociais e como se organizar a partir deles, fica mais complicada. Então, um está olhando o dia a dia, o que está ocorrendo, e o outro está pensando num futuro: "temos que mudar a sociedade, porque não tem jeito, não vai ter ônibus, não vai ter água, não vai ter casa, se não mudar o mundo, né”.

Então, é nessa trajetória que eu entro na faculdade já no Serviço Social. Volto em 81 para o Rio, vou para a UFRJ, porque a UFF não tinha ainda transferência, as transferências da UFF eram muito complicadas, e apesar de eu ter ido para Campos, em um arranjo com um tio meu que foi patrão de minha mãe, eu tinha que voltar, porque tinha que trabalhar. E também, quando cheguei aqui, a faculdade é de dia, é de dia mesmo, não tem isso de um dia a noite e outro dia de tarde, era de dia, 
então, tive que mudar toda a minha vida, organizar esses processos, ao mesmo tempo me formar e tal, enfim.

O que isso tem a ver com a minha trajetória política? É que ali, já vem desenhando um pouco da base da minha trajetória política. Em 80, quando eu vou para Campos, na ânsia de ter algum tipo de recurso - eu não pagava pensão, quem pagava era esse meu tio, que era meu patrão, eu também trabalhava para ele, eu começo a trabalhar no serviço que era uma espécie de espaço recreativo para crianças e adolescentes. Ali eu começo a trabalhar com criança e adolescente, e vou nesse trabalho até 1997. Em que pese, que ainda a questão racial é minha questão chave, mas é aí que eu trabalho todas as dimensões políticas, era profissional, era formação, profissão, ação política e criança e adolescente. A questão racial e a questão de gênero, ela vai compondo o meu aspecto profissional e político de diferentes formas. Eu já era uma militante no movimento negro, e para enfrentar a questão das crianças na rua, que também havia toda uma ação politica de outras organizações, tanto da filantropia, quando do mundo politico, trabalhando isso. E só tinha uma organização negra que trabalhava isso na época que era o CEAP [Centro de Articulação de Populações Marginalizadas], uma organização que vem do mundo das pessoas tuteladas pelo Estado, internadas desde crianças (por várias razões), e que tomam esse tema do ex-aluno para uma discussão, e eles abrem uma organização que trata das populações marginalizadas.

Nesse período, o CEAP já levantava as questões da violência, da vida na rua e tal. A questão racial então, foi pensada por mim, diferente um pouco desse aspecto da institucionalização. Os debates que fazíamos juntos, porque nós criamos fórum, nós tivemos uma ação política muito promissora, um grupo de ativistas, e de educadores, intelectuais, muito promissor, nesse tempo do avanço dos direitos da criança e do adolescente, acho que é um grupo que fez muita diferença política, em que pese que hoje a gente olha tudo e quer jogar fora, né? Mas fez muita diferença política para organizar um processo novo, tanto de políticas públicas, como de direitos no campo da criança e do adolescente. Mas, como eu trabalhava direto na rua, a minha maneira de inserir os jovens - crianças e jovens, era levando-os para as organizações do movimento negro. E aí o IPCN, que tinha lá algumas atividades como capoeira, biblioteca, tal, e os encontros, era ali que a gente, então, levava os meninos para participar das coisas. Lógico que às vezes enchia o saco das pessoas, mas a ideia era essa. Mais tarde, isso também se aplicou no movimento feminista, 
na medida em que as meninas conseguiam poder estar, não naquelas reuniões, mas em oficinas, em atividades e até em encontros. A gente começou a levar tanto para o movimento feminista, quanto para o movimento de mulheres negras, então, esse é um momento bastante importante para o sedimento da minha ação política. Então, ela segue por algum tempo no IPCN; eu fazia parte de um grupo de oposição à direção do IPCN.

Queria ressaltar outra questão importante: é nesse trabalho com criança e adolescente que nós começamos a esbarrar com as questões de gênero - olhando as meninas, o que era oferecido para elas pedagogicamente, oferecido em termos de formação, de trabalho, como elas viviam essas violências, e sobretudo, as experiências sexuais e reprodutivas. Então, assim, uma das primeiras gravidezes acompanhada por mim, no meu grupo, a menina tinha catorze anos - eu até sou madrinha do filho dela. Aí, você vai vendo que essa experiência de vivência na rua, de construção de família, de gravidez, de cuidado com a infância, e tudo mais, está muito presente, mas está também um ação política-pedagógica que às vezes se confundia, que botava essas meninas num lugar, as condenava na vida sexual e reprodutiva, e as colocava num lugar em que devia estar preparada para repetir essa trajetória de doméstica, de cuidadora, no campo da beleza, saber fazer uma unha, cuidar de um cabelo, saber limpar casa, mas nada que saísse desse escopo. E aí, então, a gente forma com um grupo, um estudo, um olhar sobre elas, isso também depois vai ser replicado em Criola, de certa forma.

Nós montamos um encontro estadual dessas meninas, que estavam tuteladas pelo Estado, que estavam na rua, que viviam em projetos sociais, para compreender sua situação, quais eram suas questões, como que elas viviam. Então fizemos vídeos, material de análise crítica sobre essa situação, montamos uma rede, montamos uma rede de educadores que trabalhavam com meninas, e mais tarde, a Criola também vai ampliar e fortalecer essa rede, oferecendo formação sobre a questão racial, formação sobre educação não sexista. Aproveitamos bastante para entender e compreender como se pensava essa menina, e porque essas propostas vinham, de certa forma, contrárias àquilo que elas viviam e pensavam.

Então, na perspectiva do feminismo, à medida que essas meninas iam tomando também mais consciência sobre o que elas viviam, era fácil incluí-las em reuniões - não tanto em reuniões, mas em oficinas e encontros, nas manifestações públicas, nos encontros nacionais, um pouco para elas compreenderem essa 
dinâmica. O que facilitava também era a presença de mulheres negras nessas ações. Então, por exemplo, você vai ao encontro, no encontro das mulheres negras, levávamos elas. Por exemplo, houve um encontro feminista em Caldas Novas, lá na região Centro-Oeste, e não tinha como a menina ficar lá uma semana sem conhecer ninguém, sem entender como funcionava aquele processo, então, as mulheres negras que iam para lá, iam acompanhando-as, orientando-as, tirando as dúvidas, mostrando como conviver naquele ambiente. Você chega no frigobar "cheio de bagulho", você acha que tem que comer, que pode comer, você quer o melhor do lugar, quer ficar mais tempo na piscina do que na reunião, então, tudo isso, as mulheres que iam com ela também ajudavam, apoiavam essa ação, ajudavam-nas nessas atividades.

Então, a minha trajetória começa assim. E já em 1992, quando eu fundei a Criola, eu já estou um pouco saturada da rua. Eu saio da rua em 1997 e resolvo não voltar mais, porque o trabalho na rua estava cada vez mais violento, eu já enterrava quatro por semana. Era assim, muito pesado, as respostas eram muito lentas, em que pese também que a política estava mudando, as prefeituras estavam com mais atenção, mas vêm as chacinas, as grandes chacinas - de Vigário, Candelária ${ }^{5}$. E aí você cansa de ficar indo nos IMLs da vida para reconhecer, para fazer aquele ritual de enterro. E havia, além desse cansaço, um esgotamento das possibilidades. $A$ violência também cresceu muito, mas os esgotamentos, porque as crianças não ficam crianças a vida inteira, elas também vão crescendo e tal. E a gente foi fazendo muita coisa junto, a gente se articulava em trabalhos só para meninas, se articulava para incluir as crianças na escola, as famílias que viviam no centro.

Nós começamos com famílias ali no Largo da Carioca. Elas estavam com muita pressão, elas estavam sendo cada vez mais empurradas de volta para os lugares de origem, e muitas vezes era bastante complexo, estava aumentando a pressão do acompanhamento às delegacias, aos presídios. Então, aquelas crianças já estavam tomando outros rumos, algumas muito bem colocadas, algumas eu ainda

\footnotetext{
${ }^{5}$ As referidas chacinas aconteceram em localidades da cidade do Rio de Janeiro, no ano de 1993 , com um pouco mais de um mês de diferença entre as duas: a chacina da Candelária ocorreu em 23 de julho e nesse massacre, 8 jovens que dormiam nas proximidades da Igreja da Candelária, foram assassinados por milicianos. Em 29 de agosto, na favela de Vigário Geral, localizada na Zona Oeste da cidade do Rio, 21 moradores foram brutalmente assassinados por um grupo de extermínio, provavelmente motivado pela morte de 4 policiais militares no dia anterior, também naquela localidade.
} 
me relaciono até hoje, outras muito mal colocadas, outras morrendo, então assim, achei que o que eu estava fazendo lá, já não tinha mais serventia.

E aí, paralelo a isso, eu já estou organizando a Criola. Em 97, a instituição onde eu trabalhava resolveu se mudar para Brasília - eu trabalhava com os jesuítas, e na hora eles me perguntam: "você quer continuar com o projeto? A gente segura a onda do projeto". Aí eu achei que, apesar de estar mais perto agora das meninas, não fazia muito sentido. Então, eu saio desse trabalho em 97. Mas já em 92, com a Criola, a gente já vai organizando encontro com as meninas de novo, formação dos educadores, articulação das instituições que atuam, porque agora também a política aumentava a tutela, a política que era para não tutelar, começou a aumentar a tutela; os abrigos, ao invés de serem abrigos que fossem resolutivos, começaram a institucionalizar, porque não conseguiam dar conta, então, era lugar para guardar criança e alguém tomar conta.

E aí, com o tempo também, e acho que não muito longe disso, há uma estratégia no movimento negro de sempre ocupar diferentes espaços políticos para levar a questão racial como chave do processo político. Como a Criola tinha muitas frentes - uma frente de saúde, uma frente de enfrentamento a violência, uma frente cultural forte, de reconhecimento e valorização da representação da mulher negra e etc, e também, cada vez mais conhecendo os problemas que as mulheres negras têm, lá para 2000, a gente tira, institucionalmente, um encaminhamento, de assim se fechar em relação à questão das mulheres negras. Então, não fazemos nada, em absoluto, que não seja dirigido, organizado e elaborado para as mulheres negras. Mesmo quando assumimos espaços gerais, o que a gente quer lá é marcar, marcar essa presença, essa possibilidade, e essa distinção, exatamente porque a mulher negra é o termômetro de tudo o que acontece no país, de bom e de ruim. Se está bom para a mulher negra, o resto está nadando de braçada; se está ruim para a mulher negra, quer dizer que a população negra está muito, muito, muito em perigo.

É assim que a gente vem fazendo ao longo do tempo, puxando determinados grupos que a gente vê em maior risco: mãe de santo, catadoras, trabalhadoras domésticas (essas, nunca sai, né? Elas também só alcançam um pouquinho mais de direito em 2015). Então, a gente vai puxando esse grupo, olhando as distintas vulnerabilidades, e vai também atravessando temas que não despontam, porque uma das questões complexas dessa ação política é que essa pessoa não pode ser separada, na saúde sexual e reprodutiva, no trabalho, na vida comunitária, na 
violência. O processo que estrutura sua vida e suas condições, ele não tem essa separação, ele pode ter uma coloração, mas a separação não existe. Não tem ninguém que esteja vivendo sua vida sexual e reprodutiva bem, se não consegue pegar ônibus, ou quando pega o ônibus está sendo violentada e discriminada, e por aí vai. Isso também exige de nós uma reflexão e uma construção tática e estratégica muito mais complexa. Porque uma coisa é você olhar a pessoa e o meio-ambiente, olhar a pessoa e a saúde, mas não é possível, quando você puxa o cobertor o pé fica de fora, quando você puxa o pé, ficam os braços. Isso exige uma complexidade na leitura do sujeito, e ao mesmo tempo, considerá-lo sujeito, ler as suas condições e encontrar nessa perspectiva, soluções que ultrapassem aquela dimensão da qual a gente está mirando. Então, olhar, por exemplo a saúde nos obriga a pensar em todo processo estrutural da saúde, por dentro, como funciona, como se estabelece política, mas a primeira premissa é impedir a morte, a discriminação.

Sim, a gente quer que o cara veja por que nós somos mais afetados pela hipertensão, pela doença falciforme. Mas se não olha a violência, também não resolve. Então, há aí um processo, que eu não chamaria desgastante, mas que precisa estar muito articulado, quase como um joguinho, senão não fecha, sabe? Assim, é como eu estou aqui com a mão entrelaçada, mas se eu botar o dedo assim, fecha um pouquinho, mas as outras pontas ficam abertas, então, esse é um trabalho bem complexo. De certa forma, é também em relação à política voltada para a população negra e mulheres negras. A política em relação à população negra melhorou muito. Isso também nos deu chance de ampliar o espectro da luta das mulheres negras, outras possibilidades. Mas elas são sempre muito mais vítimas desses processos, então, você tem que estar sempre revendo, repensando. Elas são ainda campeãs de mortes maternas. Não tem como, por mais que a gente mude agora a estratégia, vamos em justiça reprodutiva para ver como isso se estabelece. E por incrivel que pareça, assim que a Angela Davis fala, que pode ser uma verdade: toda vez que se mexe com a mulher negra se mexem as coisas. Então, você está ali há anos, batendo que tem um racismo institucionalizado na saúde, sobretudo na saúde reprodutiva. Aí vem violência institucional, violência obstétrica, aí muda tudo e ninguém quer mais olhar a dimensão do racismo, quer pegar aquele momento da ação obstétrica, quando a ação obstétrica não fala de tudo, do dia que essa mulher engravidou, como ela engravidou, porque ela está vivendo aquilo, como ela foi a última a chegar na unidade de saúde, quando ela aborta, porque ninguém 
sabia, só ela. Ela não queria contar para ninguém o que aconteceu, se isso levou à morte, por que levou. E aí, a violência obstétrica não abarca tudo, vai abarcar, até por força do sentido "obstetrícia", uma parte do processo que também precisa ser revista, relida. Mas o que ela viveu necessariamente, "de cabo a rabo" foi o racismo. Não teve acesso a uma política de direitos sexuais e reprodutivos, não teve informação suficiente, não teve acolhida nas unidades de saúde para o cuidado, não recebeu informação de qualidade, engravidou, foi condenada pela gravidez, e aí começa o seu calvário. Tudo que dá errado foi ela que fez, e tudo que dá certo ninguém sabe quem fez, mas não foi ela. É para tomar vacina no $1^{\circ}, 2^{\circ}$ e $3^{\circ}$ mês, ela vai tomar no 6․ Ela está hipertensa desde do começo, todo mundo vê que ela está hipertensa, mas chega no final, no parto, ela morre. Aí estava lá escrito, mas porque não avisaram? "É porque não sou obstetra, não sou ginecologista". Então, afinal de contas, ninguém sabe nada. E você fica pensando: "esse cara comprou esse diploma?" Por que não é possível, né? Todo mundo, até nós que temos uma profissão das mais complexas, sabemos o básico, então, não é possível que o médico não saiba o básico - sinais vitais, inchaço, coisas que qualquer pessoa, até nossa mãe que nunca passou pela medicina, sabe olhar e dizer: "essa grávida está inchada, está retendo líquido, está comendo muito, está não sei o que, né?" Eles não sabem. Então, essas mulheres vão à morte por uma circunstância de incompreensão da sua condição de gente, de ser humano, e aí vai cansando.

Muitas das nossas perspectivas como organização foi centrar, então, o olhar nessa mulher e compreender como funcionam todos esses processos... Lembrando, assim como essa mexida apareceu violência obstétrica, antes disso apareceu a Rede Cegonha, que foi pensada basicamente em cima das mulheres negras, que foi aquele debate: "está pensando em cima das mulheres negras, porque a cegonha não pode ser qualquer coisa, né?". Aí já vem as medidas e o cadastro - quer saber se ela engravidou, se ela levou a gravidez até o fim, se não levou, o que ela fez com a gravidez. Aí você tem que lutar para isso não acontecer, porque isso é um inferno. Aí agora, abre-se estudo sobre a economia e a saúde reprodutiva e se descobre que as mulheres são mais pobres, sobretudo, as mulheres negras, porque têm filhos, porque "não sei o que". Aí se pergunta sobre o contraceptivo hormonal que vai impedir dela engravidar na adolescência e na juventude, mas que mulher ela será na terceira idade? Após quarenta anos, qual mulher ela vai ser? Que deficiências físicas ela vai ter? 
Bom, enfim, é só um pouco para contar que ela é o termômetro da desigualdade, é o termômetro da violência. E o engraçado é que tudo dela é invisível, até mesmo a violência policial, porque é uma quantidade menor, ninguém nem liga. Mas se a gente for olhar mortes de mulheres negras você vai ver um negócio muito estranho, porque elas morrem dentro das vias institucionais e isso fica parecendo coisa natural. Se você tem grávidas, oito são negras e quatro morrem, você olha e fala: "bom, mas como morreu? porque morreu?" São causas evitáveis. Agora mesmo tem uma pesquisa enorme mostrando quanta gente morre de causas evitáveis, e por que não se evita essas causas? Então, é um pouco isso.

Jacqueline Botelho: Lúcia, impressionante como a violência nos marca em vários espaços. Você traz isso de forma muito nítida - na escola, nas instituições do campo da saúde. Você tem uma militância larga nesse campo, e faz também essa denúncia. Como existe essa violência policial, como existe um controle do Estado sobre os nossos corpos, um controle que, de certa forma, busca-se velar, mas nós assistimos isso de forma muito nítida. Então, nós, que a todo tempo sofremos essa violência, somos chamadas a cuidar. Acho que é muito importante, e você traz isso na sua fala, essa questão da falta de cuidado conosco, com os corpos negros, com as pessoas negras. $\mathrm{E}$ a todo tempo somos chamadas a cuidar. Você cita as domésticas, você cita sempre as mulheres nessa posição que é colocada pela sociedade. Não é a posição que as mulheres querem ocupar, mas que é reservada a elas, e você trata isso muito bem e fala também da sua militância quando se apresenta, que está relacionada com a sua vida, com a sua trajetória. E a gente queria ouvir um pouquinho - você já aborda a questão do feminismo negro, mas ouví-la um pouco mais sobre como a sua militância se relaciona com essa pauta e com os debates atuais que a ONG Criola vem tratando hoje.

Lúcia Xavier: De certa maneira, essa ideia do feminismo negro tem dois pontos de vista. Tem um pouco a crítica das negras americanas sobre a ação política do feminismo, mas ela também é a crítica brasileira do olhar das mulheres 
brancas sobre as negras no feminismo brasileiro, do que está se tratando quando se está falando na trajetória das mulheres negras e da sua invisibilidade. No primeiro ponto de vista, poucas têm alcance, e esse alcance só vai aumentar agora com as diferentes traduções, ou mesmo, com as formações de outras mulheres nos Estados Unidos, que tiveram mais contato com essas teorias, basicamente com a ampliação do conhecimento nesse campo das mulheres negras, sobretudo, das americanas.

No caso brasileiro, a história é um pouquinho diferente. Ela tem início com uma certa ruptura do movimento de mulheres, que hoje é o movimento de mulheres negras, sobre o modus operandi do feminismo brasileiro. O feminismo brasileiro faz questão de fazer essa cisão, começando a história das mulheres brasileiras a partir das primeiras sufragistas, as primeiras mulheres a tomarem posição pública na sociedade, e esquece que a gente estava aqui, ao mesmo tempo, desde do começo da escravidão, buscando por liberdade, por outro tipo de tratamento, por reconhecimento da nossa humanidade. Essa cisão, ela é tão profunda, que não precisa de nenhum texto para ler, é só você ver que a primeira onda começa sem falar de mulher negra. E depois, tem essa ideia da dimensão do direito ao trabalho.

Bom, não vou falar de domésticas porque eu acho que, ainda por cima, é um entrave até hoje. Mas vem se falando do direito ao trabalho, do reconhecimento e do direito ao trabalho de mulheres de modo geral, quando as mulheres negras já estão no mercado de trabalho há muito tempo. Já andavam pela rua - e esse não era um problema moral, porque elas não tinham nem isso, "problema moral". Como uma concepção política, ideológica, [o feminismo brasileiro] nasce em nome das mulheres, das mulheres de uma maneira universal, convivendo numa realidade completamente díspar, e logo, logo, você vai ver que a sua insuficiência no enunciado é grande.

Então, quando é muito gritante você tem: "Ah! Potiguar não sei da onde", "Ah, a mulher negra sei o que lá". Mas ela também tem esse diálogo intermediado, ela tem que ter ido para escola, e vocês sabem que, diferente dos Estados Unidos, no Brasil, esses direitos são conquistados muito lentamente. Mulheres brancas tinham conquistado o direito ao voto, mas negros ainda não tinham conquistado direito a educação. Então, você vai ver uma comparação imediata com os americanos, mas os americanos era o seguinte: ou você aprendia a fazer para te cuidar, montar sua universidade, fazer sua escola, ou você não teria nada disso. No caso do Brasil, você não podia fazer e não era aceito em nenhum desses espaços, não tinha o lugar 
de trás no ônibus - até hoje é uma pergunta que se faz: por que os jovens sentam no lugar atrás no ônibus, se aqui não teve apartheid? Por que eles sentam atrás no ônibus? Por que eles fazem isso automaticamente? Por que é melhor? Não, a pior parte do ônibus é o fim do ônibus. "Ah, porque eles querem dar um calote". Não tem nada a ver, é a experiência da segregação que segue, segue a ponto de você achar que seu lugar é ali, não importa o que você está fazendo. Então, esse feminismo brasileiro, ele de novo nasce, levando em consideração as hierarquias de raça, e ele é o primeiro a negar a existência de mulheres negras. Quer dizer, se você já vem de uma sociedade que nega a existência de mulheres negras como objeto (a escrava), passa o século, elas também não são trabalhadoras, porque para ser trabalhadoras elas deveriam estar incorporadas não só nos modos de produção da vida, mas nos direitos conquistados ao longo, e elas não são. Em sua maioria, estão no trabalho doméstico, que lembra muito o trabalho escravo. A gente pode até fingir, mas quando alguém diz que a gente é doméstica não está falando mentira, é ali que a gente se posiciona. Nosso salário é menor, e a vida é mais ou menos isso. Mas o que eu queria dizer com isso? Que essa negação e essa invisibilidade transformam o feminismo brasileiro em outra forma de opressão que se compara ao racismo. Por isso que a gente chama de racismo patriarcal. Então, quando as feministas começam a anunciar que o patriarcalismo morreu, já na década de 80 , quando se coloca os direitos das mulheres na Constituição de 88... morreu para as brancas; para as negras seguiu. E, quem sabe, para indígenas nem se aproximou.

Agora, olhando a realidade, se mulheres têm isonomia com a Constituição Brasileira, independente de branca ou não, como isso vai se estruturar na vida de cada uma é outra história. Quer dizer, a condição de cidadão e cidadã foi ganhada por nós, a condição de sujeito de direito foi ganhada por nós, mas nós não levamos. Na nossa hora o "negócio" entornou. Foi dito "para mulheres brasileiras", mas se ninguém nos reconhece como mulheres brasileiras, como a gente alcança esses direitos? Então, a partir dessa ideia é que surgiu o feminismo negro. Se essas concepções garantiram para vocês a condição de ser humano, de sujeito de direitos (também em tese), para nós eles são insuficientes. Eles não conseguiram nos dar pleno direito ao trabalho e proteção, eles não nos conseguiram dar direito à dignidade, eles não conseguiram mudar a representação negativa sobre nós. Ainda nos tratam, em determinados processos, como se fôssemos a escrava. Mas mudou, mudou bastante. 
Esse feminismo negro começa a anunciar isso: "olha, para fazer essas mudanças é preciso pensar nessa mulher e no seu cotidiano. Elas não têm direito a serviço, não têm direito ao trabalho, não tem direito a educação, não vivem em espaço sem violência”. Em que pese que a gente sempre diz que a violência contra a mulher atravessa toda as classes, vírgula, porque não é em todas as classes que se vive a violência de uma criança de 10 anos já grávida do seu padrasto. Claro, pode acontecer sim, mas compara em números, compara em projeção de resultados. Então, esse feminismo vai dizer: para ser feminismo precisa disso, daquilo e daquilo outro, e vai se intitular então como feminismo negro.

Dizem as más línguas, que é isso que existe hoje no Brasil de feminismo, que o restante está pensando de outra natureza, de outra forma, em direitos que no fundo vão acabar regulando a vida dessas mulheres. Vou dar o exemplo da "marcha das vadias", que começa a ser questionada nos Estados Unidos e aqui também. Nós somos chamadas de vadias há muito tempo, nós não queremos ser chamadas de vadias. Então, se para mulheres brancas ser chamada de vadia é um valor, para nós é desvalor total. Então, como vai se operando esses processos, esses direitos e essas formas? É isso que estamos chamando aqui de feminismo negro.

A Criola se sedimenta a partir daí, a partir de ações políticas, de teorias e concepções que enfrentam o racismo patriarcal, e agora cis heteronomartivo. Sem isso, nossas ações caem de novo em um processo de opressão, de invisibilidade. Mas isso não quer dizer que esse é o nome que nos marca, que chancela nossa participação. Por quê? Porque o movimento de mulheres negras se chama "movimento de mulheres negras", ele não se chama "movimento feminista de mulheres negras". Tem movimento feminista no movimento de mulheres negras? Tem! Tem as jovens feministas negras, tem movimento feminista negro, movimento feminista interseccional, tem movimento feminista de tudo quanto é tipo, mas o que nós prezamos é justamente essa dimensão entre o que faz o feminismo e o antirracismo. Como essa pedagogia criada pelas mulheres negras é muito mais além do que isso que é oferecido. Eu vou dar um exemplo: o movimento feminista está centrado na luta pelo direito ao aborto desde [os anos] 2000. Eu acompanho de perto esse processo, desde 2000, desde o dia em que se sentou no bar e disse "vamos fazer assim". Concordo que o aborto é um problema, mas o aborto é a quarta causa de morte de mulheres negras, então, certamente, ele não tem a importância politica que ele teria no movimento de mulheres negras, visto que elas 
estão com fome, sem trabalho, vivendo violência. Para elas, realmente é a quarta causa, não é aquela primeira causa, aquela que necessitaria de prioridade. As mulheres negras não participam dessa ação política, e muitas são criticadas por isso - "que não dão valor a esse processo". Mas isso não as leva à autonomia sexual e reprodutiva, ao contrário. Essa luta vai beneficiar? Claro, vai beneficiar, por isso a gente está lá, mas eu não posso parar toda a ação política de Criola e centrar nisso. Isso não é a chave para a ação política da Criola.

Tem mãe de santo tendo tudo que é seu destruído, tem meninas, crianças sendo violentadas. Você tem " $n$ " pragas: hoje a gente está com a pandemia do novo coronavírus, mas estão sobre ela a tríplice epidemia (a Zika, Dengue e Chikungunya), que acabou com a maioria das jovens que foram infectadas por essa epidemia, sobretudo, o Zika vírus, com seus filhos e as suas dificuldades de sobreviver nesse processo. Que revela que elas não tinham direito a saneamento básico, nem água potável. Por isso que elas se infectaram. Todas elas tinham galões de água guardados em casa para o cuidado. Então, são problemas tão complexos que, ao mexer em uma camada, você não resolve o problema, você precisa ter essa percepção mais holística. Então, o direito ao aborto é legal? Vai ser bom? Vai! Mas ele não é a chave. Se o movimento feminista acabar porque conseguiu o direito ao aborto, ótimo! Mas ele não é a chave dos problemas que as mulheres negras vivem. Agora, elas têm que desviar a atenção para isso? É claro que não vão desviar! Elas sabem onde estão as prioridades, e por isso, muitas vezes, elas são incompreendidas. Elas não fazem parte do movimento feminista, sua principal bandeira não é levantada por elas. É bem complexo.

Eu diria, hoje, que existe sim, os feminismos negros, feministas antirracistas, feministas interseccionais, jovens feministas. Mas Criola se posiciona em olhar esses processos como processos políticos, que poderão, ou não, alçar essas mulheres à condição de sujeito de direito, à condição de sujeito político. E na medida em que essas concepções e esses conceitos, de fato, incorporem a luta contra o racismo. Aí sim, elas poderão nos servir cada vez mais.

Maria Cristina Paulo Rodrigues: Eu queria trazer duas questões: uma, te ouvindo falar das domésticas, me lembrei que estava ouvindo um debate na semana passada sobre trabalho e desafios para o século $\mathrm{XXI}$, e o Márcio Pochmann, que foi presidente do 
IPEA $^{6}$, falou que o maior segmento de trabalhadores no Brasil é de empregada doméstica - são oito milhões. Isso diz muito da nossa formação social e histórica do Brasil, e o quão tardia foi a definição de direitos básicos para esse trabalho, e o quanto tem de luta também nessa instituição de direitos. Então, esse comentário reforça as reflexões que você traz. Mas também queria te ouvir sobe um outro aspecto: você já falou um pouco sobre a história da Criola, e como essa história está entrelaçada com outras. Mas, nesse percurso, o que te surpreendeu nesse trabalho com as mulheres? $\mathrm{E}$ nesse percurso de luta e existência da Criola, que projetos, ou que questões, ainda são muito importantes ou fundamentais? Queria te ouvir um pouco sobre isso.

Lúcia Xavier: Super obrigada pela questão. Eu volto um pouquinho, então, nessa questão das trabalhadoras domésticas, porque elas são, realmente, a primeira categoria profissional brasileira, e ela tem quase $80 \%$, ou um pouco mais, de mulheres negras. Mas a qualidade da proteção é muito baixa. Eu não acho que elas alcançam $60 \%$ de formalização, mesmo depois do governo Lula. O trabalho doméstico é reconhecido em 79, e elas só alcançam a primeira geração de direitos propostos na Constituição de 1988. Mesmo assim, elas alcançam menos. Acho que de 17 direitos, na Constituição de 88, elas só tinham 9 direitos previstos em lei. Elas não tinham direito a férias, a uma coisa impressionante, que é o auxílio-acidente. Muitas delas morreram caídas das janelas e era considerado suicídio, para você ter uma ideia do que significa esse processo. Mas elas têm um papel político impressionante nas nossas vidas. Em um século elas transformaram a vida da população negra, pois são elas que vão abrir o caminho para o acesso ao trabalho. Porque serviço público não era concursado, então, elas vão pedir as vagas de nível inferior e médio, artífice, motorista, segurança. São elas que vão fazer esses pedidos às suas patroas e seus patrões para o emprego dos seus filhos, seus primos, seus parentes, seus irmãos. E são elas também que vão ampliando o direito da mulher, o acesso à educação, são elas que vão ampliando o direito à educação. Inclusive, às vezes, levando essas meninas e esses meninos, ao convívio dessas famílias para

\footnotetext{
${ }^{6}$ IPEA: Instituto de Pesquisa Econômica Aplicada; fundação pública federal vinculado ao Ministério da Economia.
} 
poder alcançar educação. Então, elas transformam a vida das mulheres negras nesse período. É uma revolução silenciosa, uma revolução sem ideologia, mas é uma revolução de submissão e de opressão, porque elas pagaram o pão que 0 diabo amassou, comeram o pão que o diabo amassou para alcançar isso. Essa é uma perspectiva muito importante, porque a gente tem um hábito de atribuir isso tudo a uma ação benevolente da política, dos políticos, mas essa transformação... Claro, você ter de 2003 até hoje, essa quantidade de jovens formados na universidade é um luxo promovido pelas cotas, luta nossa, né? Mas, antes disso, havia um exército de pessoas formadas, instruídas, atuando e trabalhando, que não tinha cota. E foram essas mulheres, no seu trabalho, a partir do seu trabalho, de seu empenho de carregar nas costas a outra geração, que deu esse resultado. É claro que isso sempre será parte do mito, da ancestralidade. Nunca será contada na história porque há pouca pesquisa, pouco estudo sobre isso, mas é só você perguntar a qualquer figurão, que ele vai dizer: "minha mãe foi doméstica, trabalhou como doméstica e daí vai".

O que surpreende também, neste caso, é que quando Dilma cai e entra Temer, quando a crise aumenta, as primeiras a perder emprego foram elas, e também sofreram a primeira manobra: "Então, você sai do trabalho, ou encerra o trabalho de carteira assinada e volta a ser diarista, sabe?" Tipo, elas voltaram a cem anos atrás, de novo, com essas medidas. É um grupo que não dá para esquecer, é um grupo chave quando se fala de mulheres negras. Claro, há outras, mas esse grupo aqui não chega aos pés.

O que me surpreendeu nesse trabalho, esse tempo inteiro? Pouca coisa me surpreendeu porque eu acho que, como mulher negra eu vivo a mesma ação. Assim, eu estou sempre em confronto com a minha própria história, com a minha própria existência. Talvez se fossem minhas sobrinhas, ou uma outra geração, não tivesse tanto esse confronto. Mas essa geração, a minha geração, vive em confronto com a sua própria realidade: de onde veio, como viveu, até onde alcançou e sem poder fazer disso um valor. Não dá para colocar como prêmio na estante - "ah, fiz faculdade disso, mestrado daquilo, doutorado daquilo", porque, como diziam as nossas mães, "não fez mais do que a sua obrigação". Mas nesse trabalho com as mulheres, o que mais me surpreende, é que elas desconstroem tudo que você constrói como pedagogia, maneira de funcionar politicamente. Assim, a gente sai das nossas formações (política também), olhando para essas mulheres como pobres 
coitadas, como quem não sabe o que está fazendo, como quem precisa ser treinada, que não leem direito a realidade, fazem escolhas ruins, políticas. Mas ao contrário, elas são de uma sabedoria, elas são de uma sabedoria, assim... por isso, a gente olha essa dimensão da ancestralidade como processo, né? Elas são de uma sabedoria incrível. Por exemplo, muitas nunca mais casaram. Por que não casaram mais? Para assegurar segurança aos filhos. Essa segurança não era mais econômica nem financeira, mas é a segurança sexual, do corpo, da inviolabilidade do corpo. Você vai ver, são grupos de mulheres que não têm mais nenhum marido. "Ah, mas elas não têm liberdade no mercado sexual?" É verdade! "Elas não são as escolhidas para casar?" É verdade! Mas elas também vão construindo e engendrando estratégias de defesa do seu núcleo familiar.

Depois, você pega as ialorixás, que é um grupo extremamente complexo, eu diria. Elas têm economia, elas fazem economia, elas arregimentam grupos, elas fazem o trabalho do cuidado, elas fazem o trabalho da formação política, elas dão equilíbrio psicológico e social a qualquer pessoa, branca e preta. Mães de Santo! O que eu levo um ano para encontrar num projeto, elas fazem brincando, em um ano, uma renda enorme, inclusive poupança. Vocês acham que elas andam de ouro por quê? Porque ouro é uma coisa fácil de fazer apólices, buscar dinheiro fácil para dar retorno a um problema grave. Elas também vão fazendo uma espécie de poupança para o que elas precisam no dia a dia. Em torno, por exemplo, dos ebós. Então, você vai jogar, você paga e faz o ebó, aí você fica "puta": "Pô, tem que pagar para a pessoa cuidar? Isso não deveria ser caridade?" Como a preta velha, né? A mulher, com o barraco todo caído, vai baixar a preta velha para cuidar de alguém e ela não tem o que comer em casa. Pois elas fazem disso ganho para a família, para as famílias agregadas, para a instituição, porque quando alguém perde casa, vai morar na casa dela, vai morar no barracão. Quando você sai de lá, você pode sair, inclusive, com um farnel do que comeu no final de semana, e mais os bichos que foram usados naquelas obrigações. Então, elas são de uma engenharia política enorme.

Vocês imaginam que a maior categoria, a categoria mais bem posicionada de negros no país eram os estivadores. Pois elas tinham relação direta com eles, elas deram cargo público para eles, cargo de ogã. Eles entravam na casa delas, quando elas recolhiam um barco de laô, a primeira pessoa a chegar era esse ogã, com uma cesta de alimento para cuidar dessa figura. Aí, hoje em dia, por exemplo, quando 
você chega em um terreiro, você vê aquele bando de homem sentadinho sendo servido, você olha e fica assim: "puta que pariu, olha a opressão de gênero aí". Claro que não, eles estão sendo bem cuidados para poder servir o que eles vão dar de troca: é o trabalho em casa, é o conserto, o dinheiro, o toque para chamar os orixás. Eles não têm papel religioso, eles não entram em obrigação de ninguém, mas eles são referenciados como pais, porque quando for necessário são eles que vão acudir. $E$ se você entrar e criar qualquer problema lá, eles são os primeiros a te defender, eles tomam conta da rua, tomam conta da porta, das crianças, para ver se na hora que está todo mundo em função as crianças não estão andando pela rua. Tem todo um processo. Mas quando você entra, você fala: "olha a opressão de gênero ali. Esses caras sentados, mal levantam para tirar prato". Elas sabem o que fazer. Por quê? Porque nós, mulheres, não podemos fazer tudo, carregar o bicho, tirar o lixo para fora... elas dão um jeito, elas vão criando processos tão complexos! E quando você chega, você reclama, a primeira coisa que você faz é reclamar.

A cozinha é o lugar de maior poder que tem em uma casa de santo. Lá você controla tudo o que acontece, você controla todos os alimentos que são feitos, lá você é elogiada, ou perde a vontade de ser elogiada, lá é o espaço que você controla a casa inteira. É a pessoa mais importante do Axé? Não! Mas é a pessoa que tem mais poder, tudo o que eu precisar, até as fofocas passam por lá. E são aquelas que vão lembrar de você. Você foi na rua, elas vão lembrar: "fulana ainda não comeu". Também te castigam, e claro, mas elas vão lembrar "fulana ainda não comeu", "separa de fulana". Esse processo todo de cuidado, quando a gente olha de fora, vê o que? Outra vez, as mulheres negras. E você sabe que tem mulheres brancas no candomblé que não gostam de entrar na cozinha, porque elas acham opressão, mas ao contrário, sabemos o que elas fazem? Elas ensinam você a cozinhar, ensinam como descasca o alho, como descascar a cebola... Você fica "puta": "porra, vou ter que ficar cortando essa cebola?" Aí tempera, aí te ensina: "tá vendo como se faz? É assim que se faz". Isso vai entrando para dentro da sua vida, porque, na verdade, elas também aprendem em uma certa economia a levar isso para vida, porque o candomblé não é uma experiência religiosa, é uma experiência de vida, quase um projeto de nação. Aquilo tudo vai contigo para sua casa.

Então, o que me surpreende nesse trabalho é a capacidade delas de articular esforços para dar conta de um drama, porque a vida da mulher negra é um drama, e elas articulam esforços. É um processo. O que surpreende é a capacidade delas de 
criar e modificar processos. Na minha casa tem muitos intelectuais, e aí, às vezes, eu via minha mãe falando: "ah, fulano, tão lindinho!" O fulano chegava já contando: "fui para Holanda, para França, para Alemanha, para não sei que, falei disso..." Gosta sempre de falar de cultura negra: "falei disso, daquilo, daquilo outro". Aí, minha mãe: "Ai, que lindo! Ai, que maravilha!" Os artistas loucos, e de repente ela falava: "oh! meu Deus, como sofreu né? Tive que dar tanto dinheiro da passagem! Às vezes não tinha o que comer, vinha para cá, e hoje está tão bem". Ele não vai botar isso nunca na tese dele, né: "fui sustentado e apoiado por uma mulher negra, que lá no seu terreiro deu suporte para que eu pudesse desenvolver". Nenhum agradecimento. Mas quando ela começa contar a história, você... "ah, era isso, brigou com o pai, não tinha onde morar, veio morar aqui, passou aqui um tempo." É isso, gente, é surpreendente a capacidade delas criarem forças.

Se eu chego com a Criola, dizendo: "você tem que aprender, você tem que saber fazer", eu não adentro esse mundo, porque somos, de certa forma, hierarquizadas, vivemos em camadas. Eu sou filha de doméstica, mas, certamente, o que serão as minhas sobrinhas? O que somos como professoras universitárias, muda um pouco a maneira da gente transitar nesse mundo - se vai continuar morando em favela, se vai morar em periferia, como vai viver a vida. Mas essa hierarquização, essas camadas do que somos, não nos habilitam a dizer o que elas são, como elas vivem e porque elas vivem desse jeito. Ao contrário, habilita a pensar a possibilidade, a potência, a capacidade de transformar. Agora, lógico, uma coisa é você viver com a faca no pescoço, transformando todo dia, e outra coisa é você ter condições para viver e transformar todo dia. É nesse lugar que a gente está. Quase tudo é combinado com elas, porque esse negócio que "eu vou fazer um cursinho..." O cursinho só sai de coisas que a gente sabe que elas não têm acesso. Vão precisar aprender a mexer com as novas tecnologias. Não adianta dizer que tendo um celular vai resolver, então, a gente tem que oferecer isso. Isso é um instrumento que pode nem servir para ela, mas para amiga, ela se lembra da filha, lembra da prima, e ela bota na fita, sabe? E isso vai fazer a diferença na ação política dela: "ah, bom, eu tenho falado e fulano não tem me escutado".

Outro dia mesmo eu estava vendo uma experiência de uma moça, que seu grupo fez uma cartinha política para campanha eleitoral, e aí o grupo foi apresentar, um grupo de catadores se não me engano. Foi apresentar a tal da cartinha. Chegando lá, o cara: "pode monitorar." Elas começaram a monitorar desde do 
começo, elas já estão cheias de reuniões marcadas. Ele disse que iria fazer "não sei o que”, elas vão lá cobrar. E fomos nós que ensinamos? Claro que não, elas sabiam. Claro, se a gente ajudá-las a monitorar! Tem várias formas de ensiná-las a monitorar que facilitam, que não vai perder tanto tempo, mas elas já estão fazendo esse trabalho. E a gente sempre despreza isso. É um jeito diferente de fazer, que não combina nem conosco, nem com financiador, mas é possível ser feito. Então, acho que é um pouco isso. E outra coisa também, nós temos uma experiência de trabalho numa época em que a violência... Não tinha a lei Maria da Penha ainda, a violência contra a mulher estava muito braba. E aí, nas tradições afro brasileiras, sempre se pergunta ao mais velho, quando o negócio não está dando certo, o que fazer, né? Aí nós perguntamos a elas: "nós queríamos fazer um trabalho com [a questão da] violência. Nós temos um dinheiro aqui para fazer isso, mas a gente ainda não conseguiu, a gente queria conversar com vocês." Aí juntamos seis, e elas disseram: "tem que chamar fulana e beltrana, que ela é muito boa nisso" Aí chamamos. E aí nós explicamos para ela: "o Estado fez isso e não está dando certo, a sociedade está fazendo isso, não está dando certo." Aí ela disse: "não, a gente tem que fazer". Mas para isso a gente propôs a elas compreenderem como funcionava isso tudo. Uma coisa é elas acharem que a violência doméstica é fruto da relação homem e mulher, e outra coisa é elas imaginarem como isso se dá politicamente em todos os campos da vida. Foi isso que nós fizemos. Levamos elas para vários lugares com direito a descanso, diversão e estudo. "Olha, violência acontece assim, tem esse número, acontece assado, hoje você tem que fazer isso, aquilo e aquilo outro. O que vocês acham que pode dar independência?" Mulher que não tem independência, que não pode falar mais alto, acaba ficando submissa. Todas elas, exceto uma casa, montaram projeto de empreendedorismo. Aí, no começo, dá aquela má vontade: "ah, projeto de empreendedorismo?" Depois elas vinham trazendo a notícia: "Lúcia, fulana não tinha o que comer, agora vende pão porque abriu uma padaria, vende pão na porta de casa todos os dias". Então, todo dia ela tem como sustentar a família. Aquilo gerou compromisso? Não. Assim que ela aprendeu a fazer pão, ela seguiu fazendo pão, e ficava lá ouvindo aquelas histórias, da não violência, "você tem direito e tal". Ficou livre da dificuldade, não precisava mais esperar o homem trazer, ela mesmo já tinha condição de ir produzindo seus resultados. A outra disse: "ah, olha, minha vizinha morreu". Aí a outra: "mas por que sua vizinha morreu?" "olha, se ela sabe todo dia eu ouvia essa história aqui e pensava, tenho que falar 
isso com a minha vizinha, mas eu não falei, não deu tempo, mas agora eu vou falar". Aí botou cartaz na porta de casa: "contra violência, vem aqui conversar comigo". Depois o homem foi lá, rasgou o cartaz: "vou chamar a polícia". "Não pode chamar a polícia que o bandido não vai gostar." "Então, vamos fazer um cartãozinho para você. O que mais você precisa? "Preciso conhecer a delegada de polícia". "Então, tá bom." Fizemos uma reunião, elas conheceram a delegada de polícia. Por quê? Porque elas achavam que ao chegar lá na delegacia quem ia ficar preso eram elas. Então elas conheceram a delegada. A delegada não teve outro jeito senão dizer: "tá bom, então quando vocês forem lá, me procurem ou procurem fulana”. Então, todas as denúncias, elas iam direitinho na delegacia, falavam. Claro, tivemos que deixar o dinheiro para passagem? Claro! Mas o resultado foi bem melhor do que aquele que a gente imaginava, que ao fazer aquela palestra, aquele curso, tudo se resolveria.

E mais que isso, o empoderamento delas na região foi grande. Por quê? Elas começaram a falar com as autoridades locais, pois não tem como resolver a violência de São João no Rio de Janeiro, tem que ser lá. Então, elas também tiveram a possibilidade de dizer "sou mãe fulana".

Sabe quem abriu a maternidade Heloneida Studart? Tinha um grupo de mulheres que ficavam toda semana na porta da maternidade, dizendo que dinheiro público estava se estragando, que as mulheres estavam morrendo... tem até vídeo sobre isso. Eram elas, umas Mães de Santo que resolveram que tinha que abrir a maternidade. É claro que não foram elas que abriram a maternidade, mas elas "encheram o saco", encheram o saco da delegacia de São João para abrir, então é isso. Desculpa, nenhuma feminista vai para porta de maternidade, ou delegacia "encher o saco", são elas que sentem na pele. Então, esse esforço que elas fazem, sempre me surpreende. Sempre quando eu vou com a fórmula pronta, eu volto para casa chateada comigo. Eu falo: "poxa, não acertei dessa vez".

E a última que nós vivemos agora, foi muito engraçado. Sob meu ponto de vista, essa pandemia trazia uma solidariedade que ia terminar né, porque ninguém aguenta comprar cesta básica para dar de presente toda semana. E aí, eu fui conversar com elas: "estou muito agoniada, isso não vai dar certo, eu queria propor a vocês que a gente fizesse o cadastro do auxílio emergencial para as mulheres”. A primeira coisa que eu pensei que elas diriam era: "não vamos não, nós queremos cesta básica", Por quê? Porque eu encontrei 13 mulheres fazendo isso, catando recursos na sociedade para cesta básica. Pois você sabe que elas toparam? Nós 
tivemos quase 60 lideranças fazendo isso em mais de 10 territórios, em 10 cidades. Elas, lógico, inicialmente disseram: "ah, Lúcia, mas a gente tem que arrumar algum dinheiro, porque esses jovens já estão sem trabalho. Vão ficar presos nisso?" "Tá, a gente arruma". Arrumamos um financiador e dissemos: "olha, elas precisam ganhar", e elas toparam. Então elas faziam tudo, elas iam lá, mexendo no celular para conseguir cadastrar, elas trabalharam limpando o CPF dessas pessoas, exigindo da Caixa que desse resposta, elas foram nos CRAS, no CREAS. CRAS e CREAS fechados, unidades de saúde que não atendiam, juntaram com jovens, fizeram de tudo, gente. Fizeram jingle para cantar na comunidade sobre o coronavírus, ficavam batendo boca com pessoal para fechar o bar... porque vamos dizer a verdade, nada fechou, só o Rio de Janeiro. A maioria das cidades do entorno não teve nenhuma parada, até hoje. Você anda nos municípios, sem máscara, sem nada, nenhum aviso, nem uma carinha do corona. "Olha, eu estou aqui nessa cidade, vocês precisam se cuidar". Nada, nada. Informação zero, contando zero com as autoridades. E elas foram e fizeram.

Então, tem uma força aí que a gente nega sob o ponto de vista político da capacidade de transformação e representação. Nisso nós já estamos vacinadas, não temos problema. Ou elas nos representam, ou nos representam. Mas é sempre uma surpresa, porque você sempre fica achando que aqueles seus diplomas estão valendo mais e elas chegam com outra coisa, sabe? Elas chegam com outra coisa, dizem: "não, nada disso". E, mais que isso, nos chamam à responsabilidade. Eu sempre falo isso: "a senhora, nessa reunião, vocês deram dez tarefas, mas nós não vamos cumprir, são vocês". "Então, pera aí, Lúcia". Aí começa a negociação. "Por quê? Tem que fazer isso, tem que fazer aquilo, tem que fazer aquilo outro, tem que não sei que". E digo mais, começa sempre por cima: "oh, essa cesta está maravilhosa, mas eu nunca vi cesta para mulher não ter absorvente higiênico". A gente: "pelo amor de Deus, era só comida". "Oh, está muito bom, mas não tem leite. Como que vai sustentar as crianças sem leite?" Então, assim, você acaba sendo obrigada a rever coisas. Bom, tive que achar dinheiro para comprar leite, né? Porque o que elas estavam dizendo era: "está ótimo! Muito legal! Mas não tem leite, como ficam as crianças pequenas? Elas vão comer arroz e feijão?" Para mim estava ótimo, uma cesta maravilhosa, cheia de coisa, com uma cesta de legumes frescos, entregue na hora, kit de limpeza, máscara, mas alguém reclama do leite. Você tem que rever sabe? Porque se eu não escuto, vou dizer: "tá bom, a senhora me 
desculpe". De vez em quando elas são mais delicadas, elas falam: "Olha, está maravilhosa essa cesta, sabe o que que é? As criancinhas". Tem outras que vão dizer na lata: “Que coisa! Como é que não pensou no leite?” Tipo, não é dona de casa, não sabe que leite é fundamental? O que me surpreende nelas é sempre botar a gente na realidade, é dizer: "Oh, tu está parada aí, não é isso não."

Maria Cristina Paulo Rodrigues: Isso que você falou aqui para a gente, eu costumo falar em sala. Quando os alunos vêm: "a gente quer dar voz". Eu retruco: "Dar voz nada, as pessoas já têm voz, elas vivem dizendo o que elas querem, o que elas acham, o que elas pensam. A gente precisa ouvir, saber ouvir". Acho que a gente precisa aprender a ouvir mais e perceber. Então, assim, eu acho, que ainda que a gente saia do lugar, que tire a gente do lugar, eu acho que isso que é interessante, essa história que você conta, que é sistemática. A gente vai cheia das direções, e aí o real, esses sujeitos, que são sujeitos que lutam, que conhecem da sua realidade, vão nos ensinar. Vão dizer: "isso aqui funciona mais ou menos". É claro, tem um conhecimento que a academia possibilita, e que pode ser disponibilizado? Claro! É isso que você falou, como a gente organiza alguma questão aqui. Mas é preciso estar aberto para perceber que essa força, essa potência, ela já está lá. Então é muito bom ouvir isso de você.

Tatiana Dahmer: É sempre muito maravilhoso ouvir a Lúcia. A força da trajetória, da fala dela, do reflexo do que é a luta das mulheres negras. Eu costumo dizer que eu aprendi demais com as mulheres negras, no sentido de que não são experiências vivenciadas por mim, jamais seriam. Mas, historicamente, seja na FASE [Federação de Órgãos para Assistência Social e Educacional] e na ABONG [Associação Brasileira das Organizações Não Governamentais], foram exatamente as mulheres negras, para mim, que trouxeram o legado mais forte de organização, de resistência, de formas que não eram classificáveis naquela lógica dos movimentos sociais tradicionais, que muitas vezes invisibilizam essas mulheres. E assim, 
essa forma de resistência, seja na Baixada Fluminense, seja em vários outros lugares, que não necessariamente, como a Lúcia fala, tinham uma autonomeação de feminismo, exatamente porque o feminismo não as representava, o feminismo não as incorporava, não expressava, não materializava aquelas demandas muito concretas. E por muitas vezes, os movimentos feministas acabavam, inclusive, trazendo acusações mesmo, de divisionismo, de não fortalecimento, o que nunca foi verdade, nunca foi verdade. Então, eu fico pensando por exemplo, hoje, quando a gente fala, Lúcia, da questão da violência urbana, por exemplo, por mais que não seja a primeira forma de morte das mulheres negras, incide muito fortemente sobre elas, né? E a gente vê isso, por exemplo, na forma como as mulheres negras têm se organizado na denúncia da violência do Estado, por exemplo, do extermínio dos seus filhos, né? Das suas crianças. A gente vai em qualquer manifestação, olha para qualquer manifestação, são elas que estão na linha de frente, e assim, muito fortalecendo. Eu acho que é muito aquilo... o Emicida fez um uma coisa lindíssima, né? Um documentário lindíssimo. E "é nós por nós", né? É "nós com nós". "Nós só tem nós mesmos", né? Então, é assim e isso é muito forte. E eu acho que isso tem obrigação. Eu acho que só tem sentido qualquer tipo de luta política de militância, se a gente tiver aí, ajudando, apoiando, fortalecendo esse protagonismo, essa luta das mulheres. Isso é uma coisa que a gente aprende demais. E eu queria te dizer, Lúcia, toda vez que você fala eu fico muito emocionada, é uma coisa que me toca muito fundo, eu olho para uma história viva, um legado de resistência, de luta. A importância da Criola na própria trajetória desse campo das organizações de defesa de direitos, né? E a Jacque, por exemplo, tem sido uma pessoa muito importante na escola, porque você vem do Serviço Social e você sabe como essas hierarquias são construídas de uma forma muito pesada. Muito violenta dentro do campo das esquerdas, né? Que o que é simbólico, o que é importante é a luta de classe, depois vem o resto. E a gente está falando para um público... a gente forma meninas negras, mas as 
professoras que elas olham são brancas, em sua grande maioria. Eu nunca tive uma professora negra na minha vida, nada, a não ser as minhas professoras de luta política, tipo Lúcia, né? Mas eu nunca tive uma professora, no campo da educação formal, que fosse negra. Eu sou uma mulher que vem da elite, né. Então assim, eu queria muito esse diálogo com você, só para te dizer tudo isso. Porque, realmente, é algo muito forte, muito potente demais. $\mathrm{E}$ a própria importância da Criola, né? Tenho estado muito junto com Lia, que é uma figura espetacular, Lia Manso. E é um aprendizado, cada dia desse ano... foi um ano de trancafiamento, de isolamento, de estar nas lutas na medida do possível que a gente conseguiu. Mas um ano de aprendizado enorme, enorme, enorme! Por causa dessas mulheres, por causa desses lugares. Queria só dizer isso.

Jacqueline Botelho: Obrigada Tati, eu vou passar para Lúcia, a gente tem mais duas questões. Mas a gente pode ouvi-la porque eu acho que é super importante essa contribuição, Tati, e a gente emenda depois nas outras questões.

Lúcia Xavier: Então, eu só queria olhar, voltar em dois aspectos, um da Maria e outro da Tati antes de fazer esse último comentário. É claro que a gente olha isso como potência, como um processo positivo, mas a gente olha as contradições disso tudo, né? Porque não é possível acreditar que elas não estejam atravessadas pelo racismo, pelo sexismo, pelas LGBTfobias. Então, é evidente que eu reconheço que não dá para analisar gênero no candomblé, como se analisa na sociedade como um todo, mas eu não posso esquecer que ali também é eivado de violências. Não existe esse lugar puro, blindado, né? É eivado de violência, e eivado também de concepções de gênero, de raça, de orientação sexual, identidade de gênero, como qualquer outro lugar. Não porque são espelhos da sociedade, mas porque esses processos, eles trazem benefícios individuais, as pessoas levam essas estruturas para olhar outras, né? O que mais a gente vê nesses lugares são os brancos querendo comprar aquele conhecimento, aquele processo, aquele poder, copiar aquilo como se fosse deles. Eu geralmente os chamo de incompetentes, porque eles vão para lá fazer coisas que não conseguiram fazer no seu próprio mundo, 
entendeu? Então, se debruça para... eu conheço uma pessoa que entende tudo de samba, eu acho lindo isso. Mas ela entende tudo de samba, porque sinceramente, ela não deu para outra coisa. Aí ela olhou para o samba, que tinha pouca gente escrevendo, tinha pouca gente falando, ela virou a pessoa do samba. Ela fala mais de samba do que os sambistas, né? Ela é capaz de dizer a hora que fulano levantou, largou o tamborim e foi fazer xixi, né? Eu não vejo só beleza. Eu vejo também uma apropriação que, às vezes, é um pouco negativa. É você ouvir dizer que se não fosse Beth Carvalho não tinha samba. É mais ou menos isso. O negócio já estava lá, se ela deu visibilidade, é porque ela também tinha interesse nisso. E é claro, outras consciências, é claro que a gente precisa olhar. Como a Sueli Carneiro diz: "se você reconhece a dívida, como se alia para resolver o problema?" Mas há aí intercorrências, processos, que precisam ser vistos e questionados. Não existe esse lugar, esse ambiente totalmente liso. Senão, a ideologia não existiria, a gente estaria falando de outra coisa. Há processos ideológicos que funcionam porque determinados grupos, justamente os que serão mais vítimas desse processo, incorporam essas dinâmicas, incorporam consensualmente e violentamente.

E também aí, é importante dizer que, apesar das mulheres negras afirmarem uma maneira de fazer política, de enfrentar os problemas, elas não negam o feminismo como um propósito, ao contrário, conhecem suas vantagens e trabalham sobre elas, mas ele é insuficiente. Por isso elas vão adjetivando, é negro, é interseccional, é africano, e tem gente que nega. Diz: "não, isso não tem nada a ver, o que cabe aqui é mulherismo, não feminismo". E vão criando outras possibilidades, também porque a centralidade do feminismo só dá quem acha que ele corresponde a todas as dimensões da vida, e que sob essa égide... como a gente é de esquerda, a gente só dá valor a isso porque isso atravessa na sua formação, nosso modo de pensar. O que também é muito simples achar que só teve esse tipo de estrutura política capaz de pensar as mulheres, a desenvolver as ações das mulheres. Eu acho que o que nós fazemos bem é aproveitar bastante o que o feminismo oferece de vantagens e processos, mas lembrar da sua insuficiência é o que nos faz caminhar, isso é bastante importante. E acho também, Tati, que o reconhecimento do racismo não passa só pelo reconhecimento dos problemas e das assimetrias que vivem negros e negras. O reconhecimento do racismo, e eu não vou chamar isso de branquitude, tem a ver com o que se faz dos processos que engendram um determinado modo de poder, engendram determinado modo de organização social, 
de padrão civilizatório. E não precisa olhar para mim para ver isso, tem que olhar para si, no sentido de compreender como é que esses padrões estabelecem poder. É claro que quando Marx diz que: "somente a partir desse sujeito histórico seria capaz de transformar" é porque ele tá dizendo: "aqui ninguém vai abrir mão de nada, não, sinto muito", se não vierem tomar. E aí ele estabelece um sujeito histórico, dando a esse sujeito histórico, uma dimensão política para a luta de classes, né? Porque senão, não teria luta se não tivesse outro lado. Agora, ele olhou para onde? Ele olhou para o modo de produzir dos brancos. Só que quando a gente olha sua teoria, a gente olha do modo de organizar os outros, sabe? E essa questão, é inclusive disfarçada na dimensão da branquitude, porque vai falar da branquitude como um processo, da branquitude como racionalização. Mas olha, essa é uma dinâmica de organização da sociedade, de modus operandi do poder, da redistribuição, da geopolítica, e é daí que tem que analisar. Por que essas estruturas estabelecem e escolhem esses diferentes grupos para funcionar? Outro dia eu estava vendo alguém falar: "bom, tem árabes claros", mas a maioria dos árabes não são brancos. Como é que alguém informa, então, assim? O Egito está na África, por que a gente acha que no Egito não tinha negro? Só agora, com seus presidentes, com seus não sei o que ... É isso, por onde começa a questionar esse poder? Olhando para mim? Ao olhar para si, eu acho que você começa a compreender melhor como é que isso se estrutura como um processo de poder. Que nos atinge? Ok, é verdade. Mas o que está em jogo aí? Por que raça? Por que a distinção de raça faz parte desse processo? O que ela clama? O que ela chama? Para fazer você achar que é seu direito? Mais que seu direito, é da sua natureza esse processo de exclusão, esse processo de opressão e os derivados dele. É isso.

Jacqueline Botelho: Lúcia, quero dialogar um pouco com você sobre essa questão que você traz, sobre a força ancestral. Você fala muito da força das mulheres, do saber das mulheres negras, e eu ouvindo você falar, eu estou aqui pensando: "a gente sempre fala isso entre nós e é real". Como a gente conhece, como a gente vê! Eu tô ouvindo você falar, eu tô vendo minha tia, um pouco na história de vida dela, né? Não só como a gente se reconhece fisicamente, mas na história na trajetória, né? Muito semelhante. E você fala da força, e a gente sempre também dialoga muito sobre força, como a 
gente também precisa de apoio, a gente também precisa ser apoiada. Porque também tem essa lógica que a mulher negra, ou a casa da mulher negra, sempre vai ter um apoio, sempre vai ter um afago. $E$ eu vivi muito isso também na casa das minhas tias, que eram de santo, que faziam as festas das crianças, e ali a gente tinha um trabalho coletivo ao entorno, era sempre um lugar de receber pessoas. Mas também é importante que haja uma atenção para quem são as pessoas, as suas dificuldades, as suas condições de vida, que você trouxe aqui. O quanto que a gente não deve fazer o uso, a sociedade não deve fazer o uso abusivo dessa força, porque muitas vezes é o que parece. É uma falta de conhecimento total desse saber, dessas mulheres, que são rezadeiras, benzedeiras, que são parteiras, muitas delas, né?

E também dialogando, já entrando na terceira questão, você traz a questão da luta por educação antirracista, como que as mulheres se engajam nessa batalha mesmo pelas suas crianças, por instrução, inclusive desde o século XIX. Como que essa luta é histórica, que não está só colocada agora, a partir da $10.639 / 2003^{7}$, mas que já vem há muito, muito tempo, protagonizada por essas mulheres pretas. Aí queria que você trouxesse um pouco essa questão dos desafios e agendas de lutas. Porque você fala muito, você falou bastante das crianças e dos adolescentes, das Mães de Santo, você traz muitas questões, muitas pautas na sua fala, e se você puder trazer para gente os pontos que você elenca mais centrais desses desafios hoje, seria fundamental. Não só considerando essa conjuntura, que de certa forma você também está trazendo, essa denúncia de como existe essa maior letalidade do povo negro, não por ser um pouco doente, mas por viver essas determinações sociais de forma mais aviltante. Então, como você pode trazer prá gente a questão central das lutas, das pautas atuais, nessa conjuntura? E também a partir da história das mulheres negras.

${ }^{7}$ Essa lei, de 2003, torna obrigatório o ensino de história e cultura afro-brasileira nas escolas. 
Lúcia Xavier: Olha, as mulheres negras, em 2015, trouxeram como pauta diferentes processos, trouxeram as políticas públicas, trouxeram a questão da Justiça, trouxeram a questão do reconhecimento e do desenvolvimento, trouxeram muitas pautas, né? Isso é o que compõe a Carta das mulheres negras, da Marcha de 2015. No bojo dessas questões, elas trouxeram a necessidade de mudança do padrão de civilidade. O coro para essa mudança é o que a gente chama de "Bem Viver". Para alguns, está constituído na experiência Andina, e para outros, está constituído na própria experiência das mulheres negras aqui, o que elas são capazes de gerar enquanto concepção, ação política, experiência de vida, para a construção desse novo modelo, desse novo padrão de civilidade. Dito isso, as recomendações daquela carta, aquilo que está estabelecido lá, é a base da ação política das mulheres negras hoje. Mas se nós olharmos mais atentamente os desafios que essa agenda política apresenta no contexto atual, a violência e a pandemia estão em lugares muito especiais, primeiro porque a violência está generalizada, não no sentido de que ela é focada, mas porque não houve, desde os últimos anos, nenhum tipo de mecanismo que impedisse o excesso de violência do Estado contra a população negra. Ao contrário, foi aumentando, inclusive no que se refere à ação contra manifestações públicas e tudo mais. Então, essa ação violenta está cada vez maior, e ela não é proporcional àquilo que a gente tem ganhado, em tese, na sociedade, como estudo, como melhores cargos de trabalho. Ela não se apresenta como um processo de correlação de forças, ou luta política. Ela se apresenta num nível de perversidade, e também de controle desses grupos. E isso faz com que os movimentos, não os movimentos organizados, mas os movimentos da sociedade contra o racismo, avancem e recuem, avancem e recuem. É como se você estivesse começando avançar e, de repente, você lembrasse: "ah, mas se eu tiver aqui, eu vou ganhar um tiro", "essa pauta aí, essa pauta não é minha". Você vai avançando e recuando no processo, não vai dando a ênfase que ele precisa ter. Então, a violência é um tema que a gente não pode deixar de lado, sobretudo, porque ela atravessa o âmbito privado, os processos públicos. Está envolvido encarceramento, tortura; também está envolvida aí a violência policial, então, para qualquer lado que você olhe, a violência está presente. E eu acho que a gente subestima muito, quando fala violência do Estado. A pessoa diz: "não, isso tem a ver com a doutrina do combate ao tráfico de drogas". E quando você olha a violência doméstica: "ah, isso tem a ver com a cultura da sociedade". O nome é sempre 
mesmo, racismo. Então, olhar a violência com certo cuidado é importante. E por que a pandemia? Porque quando pandemias desse nível surgem, elas mudam muito estruturalmente a sociedade; muda valores, muda perspectiva, elas enfrentam os processos econômicos, e são sempre os mais pobres, os negros que vão pagar. É disso que a gente está falando. Ela muda a conformação familiar, muda renda, a renda individual, a renda de cada casa. Não muda só se você vai trabalhar ou não. De repente, você tem trabalho e morreram três pessoas da sua família, né? Muda muita, muita coisa. Ela também vai estabelecer algo incontrolável, né? Nós não sabemos quantas outras pessoas morrerão depois da pandemia, em decorrência dela. A pandemia, por exemplo, esse vírus constrói trombos, tem muita gente morrendo do coração, será que não tem a ver a pandemia? Fiz teste antes, fiz teste depois, não tem nada a ver, teve uma leve gripe vizinha, como diz o presidente, daqui a pouco tá enfartando, tá tendo uma síndrome qualquer. Então, tem muitas coisas ainda a serem tratadas. Mas ela é pano de fundo porque ela também ajudou a sedimentar algumas crises, sedimentou a crise econômica, a sanitária e a política. Nós vivemos em pleno desgoverno, ao mesmo tempo, continua a desmontar a política, mas na nossa cara, ele não tá fazendo escondido de ninguém. Ele vai falar do dinheiro do auxílio, ele vai falar do plano de contenção do vírus, ele imediatamente privatiza a atenção básica. Se você não olhar direitinho, já era.

Negros têm muito pouca voz política, então, precisa de muitos olhares para essas coisas, como de repente o cara está falando que vai aplicar o plano e tal e logo em seguida tem uma medida de privatização da atenção básica. Então, a pandemia levantou todos esses quadros mas, individualmente, ela trouxe também muitas encruzilhadas. Olha só, nem sei se é bem individualmente, mas olha só, se antes da pandemia, você tinha 13 milhões de pessoas comendo uma vez por dia, quantas pessoas depois da pandemia estão nessa situação? Quanto tempo elas levarão para sair dessa situação? Se você tinha, antes da pandemia, uma pessoa ganhando $R \$ 80$ por dia, para ter uma renda, mais quatro pessoas da mesma família ganhando esses mesmos $R \$ 80$, os $R \$ 600$ [do auxílio emergencial] fez efeito para quem? Sim, para muita gente fez efeito, porque você só ganhava $R \$ 80$ e agora você está ganhando $R \$ 600$, então, você não está ganhando nos 30 dias o dobro, mas você tem, regularmente, $R \$ 600$, que é o que você não teria. Você teria até mais trabalhando individualmente, mas numa busca constante. Pelo menos, no final, você tem $R \$ 600$. Então, tem muitos dilemas ainda que a pandemia apresenta. Bom, a 
questão de saneamento básico - vai ser resolvido ou não vai ser resolvido? A cidade do Rio de Janeiro toda sem água, da Zona Oeste até a Zona Norte! Também só essas duas áreas, né? Porque uma parte da Zona Leste tem água, e toda Zona Sul tem água, e o Centro também. Então você tem aí dilemas concretos, muito complexos, que a pandemia vai trazer.

A pandemia produziu para as mulheres negras uma invisibilidade e um acúmulo de trabalho, que ultrapassou, né? Na verdade, mulheres negras já têm essa rotina de trabalho, só que agora negras e brancas têm uma rotina de trabalho um pouco diferente, do cuidado da casa, do isolamento em casa, da insegurança. Então, a gente não pode tirar esse pano de fundo do retrato, ele ainda segue. Do meu ponto de vista, ele está desmontando uma das principais políticas, que é o Sistema Único de Saúde, e também está trazendo dilemas para o futuro da saúde no País. Então, acho que a pandemia vai estar sempre ali atrás e a gente olhando, tudo sem base em direitos humanos.

Depois, a Saúde. A pandemia vai nos obrigar olhar essa dimensão de saúde, não só enquanto sistema político, mas a estrutura de saúde do país: que qualidade é essa, para onde ela está indo, como ela se coliga com o meio-ambiente, como não se coliga, que expectativa você tem, como está com as próximas pandemias? Pandemias vão existir a vida toda, algumas provocadas por nós e outras. Não adianta dizer que a culpa é de quem come o morcego, de quem buscou o cachorro, quem pegou o grilo. O problema é: vamos ter novas pandemias, podemos ter uma em cima da outra, inclusive. Como é que a gente vai fazer controle ambiental, fazer um controle da vida, para evitar essas pandemias? Então, a saúde vai ser o foco. Sob o ponto de vista das mulheres negras, uma corrente está começando a crescer para o controle da natalidade de novo. Não necessariamente na mesma ordem, no mesmo valor que foi no passado, mas esse controle que vem pelo controle dos corpos, oferta de insumos hormonais, maior controle da vida sexual (e, se não pode da vida sexual, da vida reprodutiva), mais punição para aborto, mais aceitação de crianças grávidas, casamentos infantis. Não tá simples, não é? Então, eu acho que aí no campo da saúde e dos direitos sexuais e reprodutivos as coisas não ficarão muito tranquilas.

E também tem a questão ambiental, né? Como eu já comecei a falar, ela não para nessa questão da doença, da pandemia. Ela tem ainda outros entraves: nós estamos vivendo crises ambientais, climáticas, de mudanças... como chama essas 
coisas de petróleo? esqueci o nome, mas mudança de combustível, de tecnologias também, bem complicado. O mundo tecnológico é outra coisa, né? Então, acho que o ambiente vai chamar muito a nossa atenção nesse período - os resíduos sólidos, a falta de saneamento básico. Bom, tudo coligado. E é claro, na questão ambiental, não só o desmatamento, mas também a perda dos direitos indígenas, quilombolas e comunidades tradicionais vai também estar muito em voga.

Eu acho que ainda tem mais questões aí em relação ao trabalho, mas surge uma oportunidade, que é uma oportunidade complicada, que tem a ver com o novo cenário de debate político, que é o judiciário. O sistema de Justiça tem produzido coisas boas e muito ruins nesse contexto. Não tem mudado, mas tem oferecido uma arena de debate bem importante para as questões sociais brasileiras, e isso é novo, né? E a gente ainda não testou essa capacidade, de como isso vai ajudar ou não, a uma estratégia de ampliação da democracia, de afastamento das forças conservadoras, ainda não deu para gente ver.

Mas esse cara passou esse tempo inteiro sem apresentar um plano. Foi preciso o STF pedir para ele dizer que plano é, né? Ele não tá dizendo mais plano da contenção da covid, mas da distribuição da vacina. Está ruim? Tá! Não é eficaz? É verdade! Mas ele teve que fazer, e ele não ia fazer, ele não ia nem comprar vacina. Essa que é verdade. Então, a gente tem que olhar o campo da Justiça, que é um campo minadíssimo, mas que tem apresentado a possibilidade de arranjo. Eu acho que o campo do trabalho e, sobretudo, olhando as tecnologias, mudou e vai mudar mais. Assim como tem gente que nunca mais vai voltar para o escritório e vai ficar Home Office, assim também vai ter mudanças enormes na estrutura do trabalho nesse período. Não só por causa da covid, mas porque as tecnologias avançaram muito - a coisa levaria cinco anos e foi feita em meses. E só não foi feito mais porque o $5 \mathrm{G}$ ainda está em disputa, né? Quem vai botar, quem vai fazer? Mas a hora que acabar essa disputa, vão disparar novos equipamentos, novos meios de comunicação, vão mudar as regras de comunicação, e também vai mudar o acesso ao trabalho, a maneira de funcionar, de trabalhar, então, é um pouco isso.

Jacqueline Botelho: Lúcia, a gente está caminhando para a última questão da conversa. Na verdade, a gente tá aqui num diálogo muito bom, num debate muito bom. E a gente queria ouvir um pouquinho você sobre o que você pensa, como desafio e possibilidades da 
relação entre o movimento social e academia. Você começou falando da sua história, falando da universidade, falando da sua trajetória. E a partir desse seu conhecimento, dessa sua história toda de lutas, a gente queria saber um pouquinho o que você espera da Universidade na relação com os movimentos sociais.

Lúcia Xavier: Olha, para te dizer a verdade, o que eu vou falar aqui é mera conjectura, não tenho isso pensado assim, não. Mas eu, a partir de uma coisa que aconteceu na direita, isso me deixou ainda mais encafifada. Sabe quando aquela deputada paulista, que fez o impeachment da Dilma, fez um primeiro questionamento sobre o que tem produzido a academia e para que que serve? É claro, a primeira coisa é rechaçar esse tipo de pensamento. Mas depois, foi de olhar um pouquinho, né? Essa interação academia e movimentos, está muito aquém, eu acho né? Eu acho que ela já foi mais promissora. Não em pensar juntos, em construir coisas juntas, experienciar processos de conhecimento, de troca, de formação. Acho que hoje tem mais o negócio de uma fonte de pesquisa do que necessariamente uma interação, uma relação, em que pese que tem muitos acadêmicos que vieram dos movimentos. Mas eu acho que essa combinação do jogo não tem mais. Não tem mais. Eu acho que tem uma coisa mais pensada da academia para ela mesma, para sua produção, para dar conta do seu ritmo. Às vezes, os garotos vêm pedindo entrevista, você tem menino pedindo no TCC coisas que você fala: "eita, mas isso não é do mestrado?" "nossa, está estudando isso, é?".

Não é um julgamento sobre, mas sobre o que se tem produzido, e como isso ajuda ou não, as dimensões, os debates e as discussões sobre os movimentos sociais. Eu acho que a gente já foi mais pautado, mais articulado. Hoje eu acho que tem menos. Por exemplo, as meninas me procuram muito para essa coisa da justiça reprodutiva, da violência obstétrica, dos direitos sexuais e reprodutivos. Eu fico impressionada que aqueles estudos não dialogam conosco. A gente até convida para vir falar, mas eles não dialogam com aquilo que a gente está vendo na realidade, né? Por exemplo, recentemente a gente fez um esforço de judicialização da morte materna. Não tinha ninguém na academia pensando nisso, ninguém, a gente procurou. Vamos ver se elas estão pensando nisso lá no judiciário, lá nas escolas de magistratura, nas universidades. Não achamos. É claro, você tem aí toda uma corrente voltada para quem está posicionado nessas pesquisas, então, tem 
muitas discussões identitárias que são muito interessantes, muito a ver com a realidade. Mas na prática, olhando e conversando com os movimentos, elas ainda não estão. E também, tem aí uma ideia de chancela do que vem dos movimentos sociais, que podem ou não ser necessariamente alvo dos conhecimentos produzidos, entendeu? Então digamos, tenho muita questão em relação à violência do Estado, e aí, às vezes, o estudo vai falar mais da confirmação daquilo que uma mãe falou: "ah, o Estado é violento", do que necessariamente vai argumentar, pesquisar, discutir esta premissa do que significa a violência do Estado? Como a gente está posicionando isso? Se é para contar a história daquela situação ou daquela vida, ok, perfeito. Mas se é para indagar a realidade, indagar os processos, ver o comportamento do Judiciário, ver mesmo um fenômeno atroz... Não sei, eu tenho críticas. Eu também confesso que tenho lido pouca coisa, então, certamente, pode ser que eu esteja muito atrasada nesse debate. Mas o que eu tenho prestado um pouquinho mais de atenção, a partir dessa história, é a produção negra, que é uma produção complexa, que tem de tudo. Tem decolonialidade, generalidade. A pergunta é: como isso se conecta ou não com a realidade, com as questões que as pessoas estão vivendo, apresentando? Não que necessariamente os estudos precisam ter essa obrigatoriedade. Ter uma certa funcionalidade, um certo resultado, mas a maioria das produções que têm informado os movimentos, não estão vindo das universidades, estão vindo de outros grupos e de outros setores. Por exemplo, tudo de violência que ocorre você tem dois ou três fóruns, de cidadania, de segurança, o CESEC [Centro de Estudos de Segurança e Cidadania]. Necessariamente, até pode estar dentro da Universidade, mas não está articulado com a produção de conhecimento, sabe? Você tem outros meios. Agora mesmo a gente viu o JacaLab, Laboratório de Dados do Jacarezinho; o Datalab, Observatório de outra favela. Isso também ajuda. Melhorou também a capacidade de outros setores construírem dados, esses dados serem reivindicados como verídicos, legítimos e também, a partir deles, criar-se novos processos de conhecimento. Isso aí para mim é fantástico, acho muito bom. Se você vai ver como está o saneamento de parte da cidade do Rio, é através do Cocôzap ${ }^{8}$, não vai ser pelas universidades do Rio de Janeiro. Em que pese, que você sabe que deve ter alguém lá fazendo essa discussão, de outro lado, essa vida acadêmica tem empurrado as pesquisas e

\footnotetext{
${ }^{8}$ Projeto de geração cidadã de dados sobre saneamento básico em favelas do Rio de Janeiro. Disponível em: https://medium.com/cocozap. Acesso em 09/02/21 às 21h.
} 
os estudos para determinados guetos, para determinados formatos, para determinados processos. Recentemente, no último congresso da ABRASCO, que é a Associação Brasileira de Saúde Coletiva - eu faço parte do GT de Raça e Saúde e dentro do GT a gente criou um subgrupo de iniquidades em saúde -, apareceu coisas demais, coisas de profissionais e coisas da academia. Tem estudo que eu acho que é porcaria, porque falava de raça de um jeito que você fala: "de onde essa pessoa tirou isso?" E tem outros que são brilhantes, conectam as coisas e tal. Recentemente, olhando um estudo de um cara, que não sei o porquê ele estava participando desse grupo, acho que inclusive ele fala da questão racial e ele queria um pouquinho mais de conforto. Estava ele e o seu orientador na apresentação do trabalho, então quer dizer chancela. Olha que coisa interessante! Ele está olhando, onde ocorreu a tríplice epidemia, o cuidado com saneamento básico e câncer do colo do útero. Por quê? Porque quando ele começou a estudar onde estava batendo numa dada região, ele achou numa região do Nordeste, que foi o lugar que mais teve Zika vírus. Quando ele desenha o mapa, que ele puxa a incidência da tríplice epidemia, ele também puxa a coisa da água, da água do esgoto, porque a maioria desses lugares não tinha acesso a água potável. Ele descobre que essas águas todas têm alto nível de coliforme fecal, e, por causa disso, essas águas recebem mais produtos químicos do que em outros lugares. E por causa disso, não sei como, ele encontra uma incidência maior de câncer de colo do útero. Seu estudo quer saber, então, o que tem a ver essas coisas com a maior incidência de câncer de colo do útero. Quando que a gente vai conhecer isso para agir? Ele vai conseguir publicar esse estudo em uma revista especializada. Ele vai conseguir fazer um seminário para cientistas. Mas o movimento só vai saber, se estiver na academia, ou buscando esse estudo. Aqui tem uma ação de incidência política importantíssima, mas se ele não fizesse essa correlação, nada vai acontecer. Mas é para isso que os estudos são feitos? Claro que não! E se eles não estão disponíveis - e agora até que estão muito-, se eles não dialogam, a gente não consegue utilizar os resultados desse processo. Então, a gente não sabe se essa tese nasce das denúncias, se essa tese nasce da coincidência dos estudos, se essa tese nasce de um circuito, de um de uma série histórica que ele já estava seguindo com o seu orientador há muito tempo. A tese dele vai bater com a realidade? Claro que vai! Há um problema grave de saneamento básico no Brasil; há um problema grave no cuidado das águas; há um problema grave de tríplice epidemia, e por acaso, tudo isso cruzado deu câncer no 
colo de útero em mulheres. Eu acho isso. Eu não sei se o momento é novo, de novos processos, de novas estruturas, mas aquela relação direta movimento e universidade, não tem mais. Eu acho que a gente tem mais expectativa que a universidade pudesse produzir mais coisas, suas coisas só para si, suas coisas só para ciência, mas suas coisas que conectam com a sociedade. Engraçado que esse, talvez, possa ser um momento especial para isso, né? Tem muitos observatórios, por exemplo, Direitos Humanos e Covid, dentro das Universidades. Tem observatórios da Universidade que estão olhando a judicialização. Pode ser que você encontre aí uma massa de gente trabalhando para essa relação, para dar suporte a essa relação. Mas são poucos os estudos que têm embasado as discussões. Talvez o problema não seja nem os estudos, me ocorreu aqui. $\mathrm{Na}$ verdade, esse ponto é só chute, né? Vocês estão vendo, né? Mas olha só o que me ocorreu aqui. Sabe que toda vez que a gente precisa procurar dados sobre 0 presídio, mulheres, a gente vai lá na Fiocruz? A Fiocruz só trata de saúde, né? Mas aí você vai lá e você tem toda uma demanda. A Fiocruz é a instituição que mais pesquisa encarceramento. Agora, ano passado saiu "Nascer nas prisões", dali você vai descobrir todo um repositório de debate sobre saúde e aprisionamento, sobre saúde e confinamento e tal. Outro lugar é a FGV. É mais fácil você encontrar coisas de políticas públicas lá, centradas, estabelecidas. Eu não sei se é a estrutura das Universidades, ou se elas não estão preocupadas na divulgação. Tem também a UNB: todo dia, agora, quem tem relação com a UNB, recebe uma lista de lá com o livro que foi publicado. Acho que é mais da livraria e da biblioteca, do que necessariamente dos cursos. Mas são raras as vezes em que os estudos saem desses muros, né? E torno a dizer, estou falando isso de boca para fora, sem experimento. Talvez eu não seja a melhor pessoa para falar disso, mas eu via mais uma ligação né? Você sabia que determinado núcleo fazia determinado estudo e você já ia direto, né? Eu, por exemplo, quando eu quero saber de políticas públicas, vou direto à FGV. Não devia ser meu lugar preferido. Poderia ser a UFRJ, que tem todo laboratório, a UFF, que tem todo laboratório de pesquisa nesse campo de estudo. Eu não sei o que tá acontecendo não, mas o que eu tô de olho mesmo é nas pesquisas produzidas por negros. Como é que essas pesquisas estão sendo veiculadas entre nós? Como é que elas estabelecem, qual o tema que a gente tá trabalhando, se elas estão nos empurrando sobre o ponto de vista dos movimentos para outras questões, se elas só estão referendando ou dando força ao tema que a 
gente trabalhava antes, se elas estão trazendo novidades, ou se elas estão trabalhando fatiados. Por exemplo, agora, o Cebrap abriu o Cebrap Covid, se juntou com o $\mathrm{Nexo}^{9}$ (a Marcia Lima trata disso, desigualdade racial e covid. Ela não vai tratar disso a vida toda, mas o ponto chave, quando eu quero saber de desigualdade racial, eu tenho que ir lá, porque lá está todo o material, o material está organizado). A PUC fez recentemente, também, no laboratório de tecnologia, um espaço desses. Os primeiros dados sobre assimetria, raça e covid foi feito por eles. Então é isso. Acho que tem também a ver com o papel das Universidades.

Jacqueline Botelho: Sim, a gente, acha que é importante essa sua colocação. Porque faz a gente pensar também nos desafios que a universidade vem vivendo, da universidade pública. E aí, especialmente sobre a pauta antirracista, vem ocorrendo o movimento crescente aí, da gente como Universidade pensar essas pautas, a necessidade do combate ao racismo, olhando racismo institucional e estrutural, vendo como que ele está refletindo e presente nas nossas vidas, desde a educação básica, desde a infância. Então, a gente vê muito como os nossos estudantes se veem enriquecidos com essas discussões, como vêm também sedentos de longa data por esse debate, questionando a necessidade da Universidade colocar esse temas em andamento. $E$ não só em uma disciplina ou outra, mas em toda grade curricular, na pesquisa, na extensão, para que faça sentido, né? Justamente isso que você falou, para que, de fato, haja um diálogo da Universidade com a sociedade. A gente precisa de fato fortalecer as pautas de defesa da universidade pública para que a gente tenha pesquisa e extensão, né? E também fortalecidos, porque são braços importantes para os movimentos sociais, para as organizações. Como a Lúcia colocou muito bem. E dentro da Universidade, especialmente a extensão é muito pouco privilegiada, muito pouco incentivada, pouquíssimos recursos, bolsas para os estudantes.

\footnotetext{
${ }^{9}$ Nexo Jornal - um veículo de jornalismo eletrônico brasileiro independente, fundado em novembro de 2015. Disponível em: https://nexojornal.com.br
} 
Então, são pautas que estão interligadas. Por isso, você muito bem coloca ao longo da sua fala, a luta antirracista. Ela é uma luta muito maior do que elementos pontuais de combate ao preconceito, ou outras questões que são também necessárias de serem combatidas. Mas vai tocar na saúde, na educação, traz aí a denúncia da violência, todos esses elementos que você pontuou muito bem.

Eu gostaria muito de agradecer à Lúcia, dizer que é um prazer estar aqui trocando com uma militante de longa data, né? Que a gente respeita a história e trajetória. Você falando de IPCN, de vários espaços antigos de luta. Nós temos muitos desafios, não é, Lúcia, para a gente chegar nesse combate ao racismo. Mas a gente sabe o que a gente quer! A gente não quer, pelo menos não queremos, isso que nos ofertam aí. Que é um antirracismo liberal. A gente quer que, de fato, a população negra tenha direitos, tenha condições mínimas de vida, o que você colocou muito bem na sua fala. Eu vou passar para Lúcia, então, se Tati e Cris não tiverem algumas considerações. E eu gostaria de ler um poema da Conceição no final, acho que ficou tão bonita conversa e eu me senti, assim, motivada.

Maria Cristina de Paulo Rodrigues: Talvez essas questões que a Lúcia pontuou ao final, sobre a relação com a universidade, devam estar na nossa agenda de luta e de desafios, na nossa agenda da Universidade também. Assim como as reflexões que você faz nessa nossa conversa, já são também um indicativo de uma agenda que nós, do lado da Universidade, devemos incorporar também. Eu também quero só agradecer essa sua disponibilidade para estar conosco nesta tarde.

Tatiana Dahmer: Eu queria também agradecer, Lúcia. Óbvio, foi um super acerto pensar no seu nome. $E$ acho que o teu olhar sempre é muito importante para a gente. Acho que isso que a Cris fala, é uma agenda central, essa impermeabilidade de qual o sentido da produção acadêmica. Se não for para gerar conhecimento e 
fortalecer o sentido social e político mesmo, desse lugar do conhecimento, é estéril. E te agradecer demais. Acho que foram 2 horas muito, muito, muito ricas.

Lúcia Xavier: Eu que agradeço, meninas. Super obrigada. Primeiro, obrigada pela capacidade de abrir a chance da gente ficar falando ao "léu", falar à vontade. Eu acho isso muito legal, porque o que tá considerado aqui é minha própria opinião, minha maneira de pensar, de olhar as coisas e isso é muito difícil, eu sei que é muito difícil. Então, dar essa oportunidade, eu gostei bastante. E também assim, muito obrigada pela generosidade de vocês, pelo tempo, pela paciência, que foi bastante tempo, né Tati? Desejar a vocês um ano novo de muitas realizações, mais saúde, mais tranquilidade.

Jacqueline Botelho: Fiquei tão feliz de poder estar aqui nesse espaço! Agradecer também a Tati e a Cris pela oportunidade, grandes companheiras na universidade. Muito importante isso. Então, vou falar aqui, Vozes Mulheres, de Conceição Evaristo:

"A voz de minha bisavó

ecoou criança

nos porões do navio.

Ecoou lamentos

de uma infância perdida.

A voz de minha avó ecoou obediência aos brancos-donos de tudo.

A voz de minha mãe ecoou baixinho revolta no fundo das cozinhas alheias debaixo das trouxas roupagens sujas dos brancos pelo caminho empoeirado rumo à favela.

A minha voz ainda ecoa versos perplexos com rimas de sangue 
e fome.

A voz de minha filha

recolhe todas as nossas vozes

recolhe em si

as vozes mudas, caladas

engasgadas nas gargantas.

A voz de minha filha

recolhe em si

a fala e o ato.

O ontem, o hoje, o agora.

$\mathrm{Na}$ voz de minha filha

se fará ouvir a ressonância

o eco da vida-liberdade."

Jacqueline Botelho: obrigada, Lúcia 